\title{
Finding one's way around various methodological guidelines for doing rigorous case studies: A comparison of four epistemological frameworks
}

\author{
Marie José Avenier ${ }^{1}$ * \\ Catherine Thomas** \\ *Léonard de Vinci Pôle Universitaire, Business Lab, Paris-La Défense, France \\ **Université Nice Sophia Antipolis, CNRS, GREDEG, UMR 7321
}

\begin{abstract}
The expanding popularity of qualitative research, and more particularly case study research, in the field of Information Systems, Organization and Management research, seems to have been accompanied by an increasing divergence in the forms that this research takes, and by recurrent criticisms concerning its rigor. This paper develops a heuristic framework for guiding the design of a rigorous case study depending on the research's goal and epistemological framework, as well as for guiding its evaluation. It also highlights the fundamental reasons - namely the epistemological ones - for differences in the guidelines offered in the literature for conducting high quality case studies.

In agreement with numerous authors, we argue for contingent evaluation criteria. We supplement these authors' works in two ways: (1) we consider various epistemological frameworks that do not appear in the classifications that they use, especially including critical realism and pragmatic constructivism; (2) we propose a set of contingent criteria to be used as a heuristic device for critically and knowledgeably building rigorous case studies within different epistemological traditions.
\end{abstract}

Keywords: qualitative research, case study, rigor, critical realism, pragmatic constructivism

\section{Résumé}

Les études qualitatives, et plus particulièrement les études de cas, se sont fortement diffusées dans les recherches en systèmes d'information, organisation et management. Cette popularité croissante s'est accompagnée d'une multiplication des formes possibles d'études de cas, entrainant des critiques récurrentes quant à leur rigueur. Cet article propose des repères heuristiques pour guider la réalisation d'études de cas rigoureuses et leur évaluation en lien avec l'objectif et le cadre épistémologique de la recherche. Il souligne les raisons fondamentales, principalement d'ordre épistémologique, qui expliquent que des repères très différents coexistent dans la littérature au sujet de la conduite d'études de cas rigoureuses.

A la suite de nombreux auteurs, nous argumentons en faveur de critères d'évaluation contingents, adaptés au cadre épistémologique retenu pour conduire la recherche. Nous complétons leurs travaux de deux manières. Nous considérons deux cadres épistémologiques de plus en plus mobilisés dans les recherches mais encore peu discutés dans ces travaux : le réalisme critique et le constructivisme pragmatique. En outre, nous proposons une mise en perspective des différents critères d'évaluation des recherches qualitatives en lien avec le cadre épistémologique retenu, proposant ainsi un cadre heuristique pour construire de façon critique, informée et raisonnée une étude de cas rigoureuse.

Mots clés: recherche qualitative, étude de cas, rigueur, réalisme critique, constructivisme pragmatique

\footnotetext{
$1 *$ Each author contributed equally to this paper.
} 
"Underlying any form of research is a philosophy of science (...). It is better to choose a philosophy of science than to inherit one by default." Van de Ven (2007, p. 36)

\section{Introduction}

Although the amount of qualitative research being performed has soared over the last forty years, few qualitative papers end up being published in top tier academic journals such as $M I S$ Quarterly (MISQ), Organization Science and Administrative Science Quarterly (ASQ). For instance, only 22 case-study based papers were published between 1995 and 2000 in AMJ, ASQ, and SMJ (Gibbert et al., 2008), and merely 10\% of the articles published in MISQ over the period 2011-2012 were qualitative papers (Avison and Malaurent, 2013). Criticisms concerning the rigor of qualitative research have accompanied its development (Weber, 2004; Gibbert et al., 2008; Pratt, 2009).

There exist a wide variety of methodological approaches to qualitative research. These include Grounded Theorizing (Glaser and Strauss, 1967; Glaser, 2004; Charmaz, 2006); Ethnography (Garfinkel, 1967; Suchman, 1987); Case Studies (Eisenhardt, 1989, 1991; Yin, 1989, 2009; Klein and Myers, 1999; Dubé and Paré, 2003; Gioia, 2010, 2012; Wynn and Williams, 2012); Design studies (Baskerville and Pryes, 1999; Carlsson, 2007, Denyer et al., 2008; Pascal et al., 2013); Action Research (Davison et al., 2012); and Critical Research (Myers and Klein, 2011). It is difficult to classify these methods. Indeed, a case study can be conducted with methods close to ethnography (Klein and Myers, 1999) or to grounded theory (Strauss and Corbin, 1990; Gioia et al., 2012). There is also some overlap between action research and design research (Avison and Malaurent, 2013), as well as between action research and critical research (e.g. participatory action research in Kemmis and McTaggart, 2008). However, these methods all share the characteristic of being "small-N studies" (Tsoukas, 2011).

While this diversity of methods is a source of richness (Avison and Malurent, 2013), it is also a source of confusion when it comes to deciding how to conduct or evaluate a qualitative research project in practice because of the multitude of justification and evaluation guidelines. This multitude of guidelines stems not only from the diversity of methods but also from the variety of philosophies of knowledge - otherwise known as epistemological frameworks - in which these methods can be carried out (Gephart, 2004 ; Mingers, 2004; Langley and Royer, 2006 ; Smith, 2006; Yanow, 2006; Pratt, 2009). Indeed, any research project takes place within an explicit or implicit philosophy of knowledge (Van de Ven, 2007). If the research method mobilized is not consistent with, and adapted to the research's epistemological framework, the research results will be limited and superficial (Gephart, 2004), if valid at all. To move forward, certain scholars have offered guidelines that are specific to a particular epistemological framework. For instance Eisenhardt (1989, 1991), Yin (1989, 2009), and Dubé and Paré (2003) for positivism and post-positivism; Guba and Lincoln (1989), Klein and Myers (1999), and Denzin and Lincoln (2003a, 2003b) for interpretivism; Wynn and Williams (2012) for critical realism; Avenier and Parmentier Cajaiba (2012), and Albert and Couture (2014) for pragmatic constructivism; and Myers and Klein (2011) for critical studies. However, these guidelines are generic and hence cannot be straightforwardly applied. As noted by Pratt (2009) there is no accepted "boilerplate" for writing up qualitative research. So, in practice, there are still strong critiques concerning the rigor of qualitative research which have been highlighted by the editors of top tier journals in the fields of Information Systems, Organization, and Management research. For instance: "What is new here?" (Gephart, 2004); "Findings often appear to lack grounding in data" (Gephart, 2004); "Methodology is underspecified" (Gephart, 2004; Pratt, 2009); mistaking descriptive studies and grounded theorizing (Suddaby, 2006); "Telling about data, not showing it" or "Showing too much data, 
and not interpreting it", mixing guidelines offered by various authors (such as, in an example cited by Pratt (2009), striving to control for variance in an inductive narrative study), and inappropriately mixing inductive and deductive strategies (Pratt, 2009); "Insufficient theoretical contribution" (Ågerfalk, 2014).

The purpose of this paper is to offer insights that can help researchers navigate various kinds of guidelines for doing rigorous qualitative research in Information systems, Organization, and Management sciences. These insights for adapting the chosen method to the research's specific context are based upon a deep understanding of knowledge goal and the justification criteria in each epistemological framework. In other words we aim to provide insights for using qualitative methods critically and knowledgeably within a context that makes different assumptions (Mingers, 2001).

Given article length constraints, the scope of this paper is limited to addressing the quality markers of only one type of qualitative research, namely the case study method. We focus on this method for two main reasons: (1) it is the qualitative method that is most diffused in Information Systems, Organization and Management research, and (2) it can take on very diverse forms.

This paper is organized in three parts. In the first part, we examine various classifications of epistemological frameworks and briefly describe the founding assumptions of four solidly argued epistemological frameworks that are frequently mobilized in contemporary research. In the second part, we discuss how case studies can be conducted and justified in each epistemological framework. In the third part, we discuss the theoretical findings of this methodological investigation, and in the conclusion we draw their implications for (research) practice.

\section{Founding assumptions of contemporary epistemological frameworks}

Referring to Piaget's (1967) definition of epistemology as "the study of valuable knowledge constitution", we define an epistemological framework as a conception of knowledge relying on a set of mutually consistent founding assumptions relative to the subjects that epistemology addresses. Hence these assumptions concern the origin and nature of knowledge (epistemic assumptions), how it is elaborated (methodological assumptions), and how it is justified. Most epistemological frameworks also rely on founding assumptions that concern what exists (ontological assumptions). So-called "truth theories of knowledge" depend on epistemological frameworks and are directly associated with the epistemological assumptions (Klein and Myers, 1999; Sandberg, 2005; Boisot and McKelvey, 2010). They specify knowledge's status and generation goal.

\subsection{A variety of classifications}

To date, there is no general agreement among scholars on how to classify the epistemological frameworks frequently mobilized in contemporary research in Information Systems, Organization and Management sciences. A traditional classification relies on a dualistic partition between positivism and anti-positivism (Wicks and Freeman, 1998) or positivism and interpretivism (Weber, 2004; Goldkul, 2008). Other classifications distinguish between foundational, quasi-foundational, and non-foundational epistemological frameworks (Amis and Silk, 2008); between various currents within interpretivism and postpositivism (Cunliffe, 2011, in an updating of Morgan and Smircich's (1980) typology); between positivism, interpretivism and critical research (Orlikowski and Baroudi, 1991); between positivism, postpositivism, critical theory (and related theorizing), constructivism, and participatory inquiry (Guba and Lincoln, 2007); and between logical positivism, relativism, pragmatism, and realism (Van de Ven, 2007). In the latter classification, Van de Ven further distinguishes between two different traditions within realism, namely scientific realism and critical realism. 
The critical realist framework has been increasingly mobilized over the past 10 years particularly in IS research (see MISQ's SI on critical realism in IS research, 2013).

Amidst this lack of consensus, there exist a number of epistemological frameworks that rely on explicitly stated founding assumptions that are mutually consistent and shared within various contemporary communities of researchers. These epistemological frameworks are those of positivism and post-positivism, critical realism, pragmatic constructivism, and interpretivism. Because of the increasing diffusion of these four epistemological frameworks in Information Systems, Organization, and Management research we will concentrate on them in the present paper.

It is noteworthy that in contrast to Orlikowski and Baroudi (1991), we do not consider critical research (nor participatory inquiry) as a philosophy of knowledge that would stand on an equal footing with positivism and interpretivism (Orlikowski and Baroudi, 1991; Myers and Klein, 2011). Rather, along with Rowe (2009), we view critical research as a methodological approach guided by a systematic intention of critique of what, in an IS, may hinder the blossoming of human potential. It can be knowledgeably and critically adapted to be conducted in various epistemological frameworks (Stahl, 2008 quoted by Rowe, 2009; Guba and Lincoln, 2007; Rowe, 2009), particularly those that posit both epistemic and ontological relativism, like interpretivism (Rowe, 2009). Indeed, for Myers and Klein (2011), it is easier to bridge critical and interpretive research than it is to bridge critical and positivist research; more precisely, the affinity between interpretive and critical research is much closer than that of either one to positivist research.

In addition, given that the mobilization of critical research in frameworks that posit ontological realism is still subject to caution, in this paper we will solely discuss it in an interpretivist framework.

\subsection{Brief presentation of the epistemological frameworks considered in this paper}

The various epistemological traditions are presented in an ideal-typical fashion: currents within each of these traditions share core founding assumptions but may differ on certain nuances. More precisely, the authors that are cited do not necessarily have a uniform conception of the tradition to which they are associated, particularly in the interpretivist tradition as well as in the positivist and post-positivist ones. Moreover, as detailed in $§ 1.2 .3$, there is an important difference between the French and the English constructivist traditions, the French one being associated with pragmatism and the English one with social constructivism (Lincoln and Lynham, 2011) and post-modernism (Avenier, 2011).

\subsubsection{Positivism and post-positivism}

Positivism posits ontological and epistemic realism. More precisely it posits the existence of an objective world that can be described and represented in a direct mirror-like manner (Gephart, 2013). As such, truth arises from a correspondence between a claim and empirically observed facts (Boisot and McKelvey, 2010).

Since Popper (1959), post-positivism differs from positivism by criticizing the role of induction wherein universal laws could be derived from a set of particular observations; hence, one can only falsify, but not confirm, hypotheses (Gephart, 2013). According to Weber (2004), contemporary post-positivist researchers recognize the limitation of the knowledge they seek to build, understanding that their culture, experience, history (and so on) impact the research work they undertake and thus their results. More recently, scholars challenged this framework outlining that social sciences have to deal with complex, messy interactive and dynamic social processes characterizing human social behavior (Boisot and McKelvey, 2010). Recognizing this complexity directs the authors to a scientific realist framework; in this framework, exploration becomes crucial, abductive reasoning allows discovering underlying patterns; justification of knowledge resides primarily in its contribution to efficacious 
adaptability and survival rather than to the attainment of a predictive law-like truth (Boisot and McKelvey, 2010).

The diversity of currents within the positivist and post-positivist traditions generate richness. It also constitutes a weakness because of the possible risks of inconsistency within research projects carried out in this tradition (Smith, 2006). For example, the statistical techniques used in positivism and post-positivism for testing hypotheses are not compatible with the assumption of complex reality frequently made in IS, Organization or Management research. Indeed, these techniques rely on Gaussian probability distributions. Those are based upon an ontological assumption of atomistic reality which "assumes that human beings are autonomous subjects, whose interests and desires are transparent to themselves and independent from the interests and desires of others" (Calas and Smircich, 1999, in Boisot and McKelvey, 2010: 418). This atomistic ontology is not compatible with the assumption of complex reality which emphasizes interdependency (Boisot and McKelvey, 2010). In a more general way Smith (2006), as a critical realist, outlines that the positivist notion of causality defined as the empirical conjunction of events is inconsistent with the experience of Information Systems research.

\subsubsection{Critical realism}

Critical realism has been developing for some years from the foundational work of Roy Baskar (1978). There has been a growing interest, particularly in the field of Information Systems (Mingers et al., 2013). Indeed, an increasing number of researchers argue that critical realism could provide a coherent and robust underpinning philosophy (Carlsson, 2007; De Vaujany, 2008; Mingers, 2004; Mingers et al., 2013) and thus resolve some long standing theory-practice inconsistencies identified in research conducted within the standard account of the frameworks of positivism and interpretivism (Smith, 2006).

The term "critical realism" arose from the combination of the terms "transcendental realism" and "critical naturalism" (Bhaskar, 1998a). As such, critical realism defends a strong realist ontological assumption that posits that there exists a world independent of our knowledge (intransitive dimension); and even though it recognizes the specificity and the emergent properties of the social realm, it asserts that "social sciences can be sciences in exactly the same sense as natural ones" (Bhaskar, 1998a: xvii). At the same time, critical realism accepts the relativism of knowledge (epistemic relativism - transitive dimension) which is socially and historically constructed. Nevertheless, epistemic relativity does not mean judgmental relativity, i.e. that all theoretical productions are equally valid; once expressed theoretical productions become available for investigation and it is possible to eliminate alternative explanations by empirically testing their potential effects (Mingers, 2004).

In line with transcendental realism, critical realism develops a stratified conception of the world. More precisely it posits that the real domain is composed of generative mechanisms and structures, existing independently from, but capable of producing patterns of events that we observe; the actual domain is the domain in which observed events occur; the empirical domain is the domain of experienced events (Bhaskar, 1978, 1998b). Generative mechanisms and structures have emergent power, and whether this power manifests or not depends on the contextual conditions; in other words, social structures have emergent powers that are irreducible to those of their constituent parts (Tsoukas, 1989). Thus, causal explanation is not about the deterministic association of patterns of events but the activation (or non-activation) of causal powers under certain conditions (Tsoukas, 1989). Here, researchers aim to know what are the structures, the generative mechanisms and the contextual conditions responsible for the patterns of events observed.

Finally, for Bhaskar (1998b) the specificity of social sciences is that objects of social scientific inquiry only ever manifest themselves in open systems; thus the absence of closed 
systems denies the possibility of decisive test and prediction. This means that criteria for the development of theories in social sciences "must be explanatory and non-predictive" (Bhaskar, 1998d, p. 225).

\subsubsection{Pragmatic constructivism}

Piaget is the first author who introduced the notion of "constructivist epistemology" in 1967. Glasersfeld's (1984, 2001, 2005) radical constructivism is in the direct lineage of Piaget's constructivism. Pragmatic constructivism is another name for radical constructivism, which has also been called "teleological constructivism" (Le Moigne, 2001; Avenier, 2010) to underscore the teleological character of the knowledge process in this epistemological framework, a feature that Le Moigne (1995) emphasizes in his refinements of Glasersfeld's radical constructivism - and to which Le Moigne fully subscribes.

The qualifying term "pragmatic" has been considered preferable to the other two labels because it highlights that, in this epistemological framework, knowledge claims justification and testing is performed in relation with intentional actions these claims are considered to illuminate (Avenier and Parmentier Cajaiba, 2012). Hence the term "pragmatic" is taken in its philosophical sense, and particularly the sense associated with the work of the pragmatist philosophers William James (1976/1912) and John Dewey (1938). Consequently, pragmatic constructivism corresponds to the kind of pragmatism that Ågerfalk (2010) suggests exploring for design science, and that Goldkuhl (2012) considers to constitute an appropriate philosophy for action research and design research.

The term "pragmatic" has also been considered preferable to that of "radical", because the qualifying term "radical" sparked a certain amount of confusion in the understanding of this epistemological framework. Indeed, it has often been interpreted to mean that "[radical] constructivism denies reality. But this it does not. It only denies that we can rationally know a reality beyond our experience" (Glasersfeld, 2001, italics in the original text).

In 2005, Glasersfeld explained why he used the epithet "radical" for the first time in 1974, in a contribution presenting his interpretation of Piaget's constructivism: "It was intended in the sense that William James (1976) [originally published in 1912] had used in his radical empiricism, i.e., meaning "going to the roots" or "uncompromising". I chose it because at the time many developmental psychologists were mentioning Piaget's constructivism but without going into its epistemological implications. What they called construction seemed to refer to the fact that children acquire adult knowledge not all at once, but in small pieces. I did not think that this was a revelation and therefore called their approach "trivial constructivism"" (Glasersfeld, 2005, p. 10).

Hence Glasersfeld used the qualifying term "radical" solely to differentiate his conception of constructivism from what he called a "trivial" conception of constructivism, rather than from a possibly "moderate" conception of constructivism - as it is sometimes thought or asserted (e.g. Van den Belt, 2003).

The epistemic assumption posited in pragmatic constructivism - namely that, in the knowledge process, whatever stems from the situation under investigation is inseparably intertwined with whatever stems from the inquirer - leads to epistemic relativism. As explained in $\S 2.4 .2$ below, this epistemic relativity does not mean that "anything goes".

A peculiarity of this epistemological framework is that, because of the epistemic assumption it posits, and differently from all the other epistemological frameworks, it refuses to posit any founding ontological assumptions (Glasersfeld, 2001; Avenier, 2010). In particular, this makes the pragmatic constructivist epistemological framework fundamentally different from 
Guba and Lincoln's (1989) "constructivist paradigm". Indeed, the latter posits a founding ontological assumption of "relativist ontology" which asserts the relative character of whatever exists that attaches this paradigm to post-modernism rather than to pragmatism (Avenier, 2011). This assumption, together with the epistemic assumption it posits, makes it judicious to classify Guba and Lincoln's (1989) "constructivist paradigm" in interpretivism, as Guba and Lincoln themselves suggest in the following statement: "The constructivist paradigm also called the naturalistic, hermeneutic, or interpretive paradigm (with slight shadings in meaning)..." (Guba and Lincoln, 1989, p. 83).

\subsubsection{Interpretivism}

Yanow (2006) depicts interpretivism as an umbrella term subsuming different schools of thought, including those drawing (explicitly or implicitly) on phenomenology, hermeneutics, or (some) Frankfurt School critical theory (e.g. Habermas, 1972) along with symbolic interactionism and ethnomethodology, among others. This is in agreement with Klein and Myers' (1999) as well as Sandberg's (2005) views of interpretivism, which underscore that there are fairly different forms of interpretivism. For instance (see Table 1 in $\S 1.3$ ), at one extreme Sandberg's (2005) conception has significant overlap with pragmatic constructivism; at the other extreme Guba and Lincoln's (1989) "constructivist paradigm" falls within postmodernism (Avenier, 2011); Klein and Myers' (1999) conception, which specifically focuses on interpretive research of a hermeneutic nature, occupies a sort of middle ground.

Interpretive research can be more or less critical in its "reading" of the social world behind the words of the actors, as a world characterized by power structures, vested interests, and limited resources to meet the goals of various actors who construct and enact this social world (Klein and Myers, 1999).

All these diverse schools of thought share a common phenomenological base that stipulates that human and world are inextricably related through lived experience (Sandberg, 2005). In particular, our knowledge of reality is gained only through social constructions such as language, consciousness, shared meanings, documents, tools, and other artifacts (Klein and Myers, 1999). Interpretive research attempts to understand phenomena through the meanings that people assign to them (Orlikowski and Baroudi, 1991). It posits social construction that reserves agency to actors and, thereby, possibilities of changes subject to various kinds of constraints. Some authors such as Sandberg (2005) posit the intersubjective character of social situations to refer to the habits of thinking, the ways of seeing and the shared meanings among members of a group who have been interacting over time, which knit these people together. This leads this author to posit that "the agreed meaning constitutes the objective, intersubjective reality" (Sandberg, 2005, pp. 47-48).

\subsection{Schematic overview of the epistemological frameworks' founding assumptions}

Table 1 below offers a schematic overview of the epistemological frameworks' founding assumptions. It is based upon a variety of texts (Bhaskar, 1978 and 1998a, b, c, d; Guba and Lincoln, 1989; Orlikowsky and Bouroudi, 1991; Gephart, 2004; Boisot and McKelvey, 2010; Avenier and Gavard-Perret, 2012...).

The columns of Table 1 represent ideal-types. Within each ideal-type, there may exist diverse schools of thought that introduce various nuances and slight differences in certain assumptions, particularly in positivism and interpretivism. For instance, Guba and Lincoln

\footnotetext{
2 Guba and Lincoln's (1989) "constructivist paradigm" is the conception of constructivism that is most diffused in the English academic literature in IS, Organization and Management research, whereas in the French academic literature in IS pragmatic constructivism is broadly diffused (Rowe, 2009) and Guba and Lincoln's conception is little known.
} 
(2007) consider that the only generalization possible in interpretivism is descriptive generalization whereas Klein and Myers emphasize the goals of generalization in interpretive research (Klein and Myers, 1999) and of improvement of social theories in critical research carried out in an interpretive framework (Myers and Klein, 2011).

The first two lines of Table 1 summarize epistemic and ontological founding assumptions that were discussed in $§ 1.2$. So, in this section, we mainly focus on Table 1's last two lines. They synthesize the specific nature of the knowledge developed in each epistemological framework by specifying the goal of the knowledge generation process and the status of knowledge in each framework. This enables us to highlight that the goals of the knowledge generation process differ across the various epistemological frameworks, and to draw the reader's attention to the crucial importance of these two aspects both for research and management practice. Indeed, on the one hand, the research goal is what guides the empirical study's design as well as the nature of the theoretical contribution. On the other hand, knowledge status conditions the way the generated knowledge can be used in IS, Management and Organization practice.

Below in this section, we first specify the goal of knowledge generation in the various epistemological frameworks, and then turn to the status of generated knowledge in these frameworks.

In the positivist and post-positivist traditions the science project aims to record constant conjunctions of observable events (Mingers, 2013). As such, the goal is mainly to identify surface similarities and patterns between various instances of the phenomenon under study. In critical realism, the goal is to identify underlying structures and generative mechanisms that give rise to the flux of phenomena under study. The identification of generative mechanisms is usually performed as a two-step process: the first step aims at inductively identifying patterns. The second and main step consists of formulating conjectures on the plausible underlying generative mechanisms and the contingent manner through which they are activated, which would explain the observed patterns (Bhaskar, 1998c). To accomplish this, abduction (also called retroduction, Bhaskar, 1998a) appears to be the most appropriate mode of reasoning (Mingers, 2004; Van de Ven, 2007; Boisot and McKelvey, 2010). Thus theoretical explanation proceeds by Describing the significant features of the events, Retroducing possible causes, i.e. generative mechanisms, Eliminating possible alternative explanations and Identifying the generative mechanisms at work (the DREI process, Bhaskar, 1998a; Mingers, 2013). In pragmatic constructivism, the goal is to intelligibly build models that are functionally fitted to experience and help to order the domain of experience (Glasersfeld, 2001). This is basically achieved, as in critical realism, through induction, abduction and conceptual assimilation (Glasersfeld, 2001; Le Moigne, 1995). In interpretivism, the goal is to understand how human beings make individual and/or collective sense of their particular world and engage in situations (Klein and Myers, 1999; Sandberg, 2005). This diversity of meanings sometimes coalesces around consensus (Guba and Lincoln, 2007). Another possible goal is to attempt to relate particulars identified in some context to 
Table 1: Founding assumptions concerning knowledge's origin and nature in alternative epistemological frameworks

\begin{tabular}{|c|c|c|c|c|}
\hline & $\begin{array}{l}\quad \text { Post-positivism } \\
\text { (Based upon Boisot \& } \\
\text { McKelvey, 2010; } \\
\text { Gephart, 2013...) }\end{array}$ & $\begin{array}{l}\text { Critical realism } \\
\text { (Bhaskar, 1978, 1998a,b,c,d; } \\
\text { Mingers, 2004; Mingers et al., } \\
\text { 2013; Smith, 2006) }\end{array}$ & $\begin{array}{l}\text { Radical (also called } \\
\text { pragmatic) constructivism } \\
\text { (Glasersfeld, 1984, 2001; Le } \\
\text { Moigne,1995, 2001) }\end{array}$ & $\begin{array}{l}\text { Interpretivism } \\
\text { (Orlikowski \& Baroudi, 1991; Guba } \\
\& \text { Lincoln, 1989, 2007; Klein \& } \\
\text { Myers, 1999; Sandberg, 2005; Yanow } \\
\text { \& Schwartz-Shea, 2006; Myers \& } \\
\text { Klein, 2011) }\end{array}$ \\
\hline $\begin{array}{l}\text { Ontological } \\
\text { founding } \\
\text { assumptions }\end{array}$ & $\begin{array}{l}\text { Ontological realism: } \\
\text { Reality exists prior to } \\
\text { and independently from } \\
\text { human attention. } \\
\text { There exists a unique } \\
\text { immutable "real-as-is". }\end{array}$ & $\begin{array}{l}\text { Ontological realism: Reality exists } \\
\text { independently from human } \\
\text { attention. } \\
\text { Reality is both intransitive and } \\
\text { stratified. } \\
\text { Reality is constituted of three } \\
\text { overlapping domains, those of the } \\
\text { real, the actual, and the empirical. } \\
\text { Generative mechanisms (GMs) } \\
\text { reside in the real domain. } \\
\text { Observable events occur in the } \\
\text { actual domain. Experienced events } \\
\text { lie in the empirical domain. }\end{array}$ & $\begin{array}{l}\text { Humans experience resistance } \\
\text { to their actions. } \\
\text { No founding assumption on } \\
\text { whatever resists human action. } \\
\text { Whatever resists human action } \\
\text { possibly exists independently } \\
\text { of human attention. }\end{array}$ & $\begin{array}{l}\text { Ontological relativism: there exist } \\
\text { multiple socially constructed realities } \\
\text { not governed by any natural laws, } \\
\text { causal or otherwise (Guba \& Lincoln, } \\
\text { 1989). } \\
\text { The agreed meanings about a } \\
\text { situation constitute the objective, } \\
\text { inter-subjective reality of this } \\
\text { situation (Sandberg, 2005). }\end{array}$ \\
\hline $\begin{array}{l}\text { Epistemic } \\
\text { founding } \\
\text { assumptions }\end{array}$ & $\begin{array}{lr}\text { Epistemic } & \text { realism: } \\
\text { Real-as-is is knowable } \\
\text { (with } \\
\text { fallibility } & \text { possible } \\
\text { measurement } & \\
\text { instruments). } & \end{array}$ & $\begin{array}{l}\text { Epistemic relativism, but not } \\
\text { judgmental relativism. } \\
\text { The real domain is not observable. } \\
\text { Events (actual domain) are } \\
\text { observable. Experienced events } \\
\text { (empirical domain) are knowable. }\end{array}$ & $\begin{array}{l}\text { Epistemic relativism in the } \\
\text { following sense: human } \\
\text { experience is knowable, and in } \\
\text { the know-ledge process, } \\
\text { whatever stems from a situation } \\
\text { is inseparably intertwined with } \\
\text { whatever stems from the } \\
\text { inquirer. } \\
\text { The intention of inquiring } \\
\text { influences the inquirer's } \\
\text { experience of the situation. }\end{array}$ & $\begin{array}{l}\text { Epistemic relativism: 'Facts' are } \\
\text { produced as part and parcel of the } \\
\text { social interaction of the researchers } \\
\text { with the participants and knowledge } \\
\text { is gained only through social } \\
\text { constructions. } \\
\text { Lived experience is knowable. } \\
\text { Intentionality has a constitutive power } \\
\text { on the meaning of reality that appears } \\
\text { to us in our lived experience. }\end{array}$ \\
\hline
\end{tabular}




\begin{tabular}{|c|c|c|c|c|}
\hline $\begin{array}{l}\text { Goal of the } \\
\text { knowledge } \\
\text { generation } \\
\text { process }\end{array}$ & $\begin{array}{lr}\text { Record } & \text { constant } \\
\text { conjunctions } & \text { of } \\
\text { observable events. } \\
\text { Identify r surface } \\
\text { regularities } & \text { and } \\
\text { patterns. } & \end{array}$ & $\begin{array}{l}\text { Identify the GMs that are } \\
\text { responsible for the events and } \\
\text { patterns of events observed, as well } \\
\text { as the manner by which GMs are } \\
\text { contingently activated. } \\
\text { The DREI process. }\end{array}$ & $\begin{array}{l}\text { Build intelligible models of } \\
\text { human active experience, } \\
\text { which provide insights for } \\
\text { organizing the world of } \\
\text { experience. }\end{array}$ & $\begin{array}{l}\text { Understand how human beings make } \\
\text { individual and/or collective sense of } \\
\text { their particular world and engage in } \\
\text { situations. }\end{array}$ \\
\hline $\begin{array}{l}\text { Status } \\
\text { and shape of } \\
\text { knowledge }\end{array}$ & $\begin{array}{l}\text { Correspondence } \\
\text { conception } \\
\text { knowledge. } \\
\text { Iconic representation of } \\
\text { real-as-is. } \\
\text { Falsifiable statements. }\end{array}$ & $\begin{array}{l}\text { Towards a correspondence } \\
\text { conception of GMs, and a pragmatic } \\
\text { conception of the manner they are } \\
\text { activated. } \\
\text { Field testable statements concerning } \\
\text { GMs and activable propositions. }\end{array}$ & $\begin{array}{l}\text { Plausible interpretations that fit } \\
\text { experience and are viable for } \\
\text { intentionally acting. } \\
\text { Generic models and activable } \\
\text { propositions. }\end{array}$ & 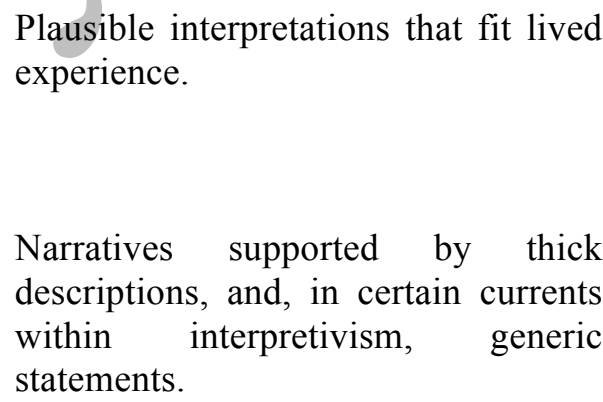 \\
\hline
\end{tabular}

\section{0}


very abstract categories and concepts that can illuminate multiple situations (Klein and Myers, 1999; Sandberg, 2005).

The taxonomy of theory types proposed by Gregor (2006) highlights that the positivist and post-positivist tradition favors either prediction, or explanation and prediction; critical realism and pragmatic constructivism emphasize explanation; and interpretivism privileges analysis or explanation. However, if each epistemological tradition aims more or less at building explanations, the ways to build explanations, to generalize them, and to use them for acting are very different depending on the epistemological framework in which the research is conducted.

Concerning knowledge status, in the positivist and post-positivist traditions knowledge represents the world "as it is": the world and the knowledge of the world "may be viewed as surfaces whose points are in isomorphic correspondence" (Bhaskar, 1998b, p. 19).

In critical realism the status of knowledge relative to generative mechanisms is not fully decided. Some authors adopt a correspondence conception of generative mechanisms although they admit that the verification or falsification of this knowledge will never be conclusive (Tsang and Kwan, 1999; Tsang, 2006). In this line, authors acknowledge that a perfect match between theories and reality is unlikely, resulting in a base of knowledge that is fallible but presumably less so over time (Wynn and Williams, 2012). In other words, they search for an approximation of reality. Tsang (2006) points out that the correspondence conception of knowledge should only concern the central assumptions of theories. Other authors like Denyer et al. (2008) and Pascal et al. (2013) favor a pragmatic conception of knowledge, focusing on what these generative mechanisms do in the empirical world, i.e. their observable effects. As noted by Tsoukas (2000), one can never be certain whether one has got into the "nature" of an object of study, i.e. has represented it as it is.

In pragmatic constructivism, the conception of knowledge is pragmatic: knowledge has the status of plausible interpretations that fit experience and offer viable markers for intentionally acting. More precisely, knowledge does not pretend to reflect world-as-possibly-functions; rather, it aims at offering viable ways and means of acting and thinking that allow one to attain the goals one happens to have chosen (Glasersfeld, 2001). Consequently, in IS, Management, and Organization practice, knowledge is to be used as heuristic markers for thinking and acting, rather than as offering precise rules to be followed to the letter. It is also used as a "sensitizing device" to view the world in a certain way, according to the phrase used by Klein and Myers (1999) to depict the way knowledge is used in interpretivism.

In interpretivism knowledge has the status of informed construction (Guba and Lincoln, 1989) in which there is agreement between the researcher's interpretation of the phenomenon being studied and the meaning given in lived experience by the individuals involved in this phenomenon. This agreement is progressively achieved through an iterative process.

In critical research carried out in an interpretivist framework, knowledge is specifically used as heuristic markers that guide transformative redefinitions (Myers and Klein, 2011).

Now that the conception of knowledge in each of the four epistemological frameworks considered in this article has been specified, we can discuss how to develop valuable knowledge in each of these frameworks, limiting ourselves to the case of a qualitative method that is widely diffused in IS, Organization and Management research, but can take on very diverse forms: the case study method. 


\section{Justification of case study quality in contemporary epistemological frameworks}

After a short description of generic principles and notions for case study quality, we successively examine the specific meanings taken on by the notion of reliability, how internal quality is justified, the goal of the theoretical contribution, and the ways generalization is performed and tested in case studies carried out in the four epistemological frameworks considered in this paper.

\subsection{Generic notions and principles for case study quality}

The quest for research quality is based on generic notions and principles such as reliability, inferences quality, constructs quality and generalization, which are fundamental in any research project that intends to be recognized as being rigorously conducted (Gibbert et al., 2008). The spirit of these principles holds regardless of the research project's epistemological framework. However, their specific meaning, and hence the way they are justified and evaluated depend on the research's epistemological framework (Amis and Silk, 2008; Avenier and Gavard-Perret, 2012). For example, to mark the difference of meanings that the notion of reliability has in certain frameworks, the term "reliability" is sometimes replaced by "truthfulness" (Sandberg, 2005), "trustworthiness" (Guba and Lincoln, 1989; Schwartz-Shea 2006) and/or by "credibility" (Charmaz, 2006) in interpretivist frameworks. We prefer to use the same term of reliability for all the epistemological frameworks, but underscore that this term takes on different meanings in different epistemological frameworks.

Quality of inferences and constructs depends on the rigor and the pertinence of the data collection and analysis. Construct quality is defined as the ability to create clear classifications of phenomena that structure experience into meaningful categories (Suddaby, 2010). As such, construct quality is first related to the quality of data collection and inferences that progressively allow the researcher to abstract a construct from the data (Tsoukas, 2011). Second, it is also related to the logical connections between the proposed new construct and other existing constructs (Suddaby, 2010). In other words, researchers need to precisely indicate the literature from which they are drawing and to which they are contributing (Suddaby, 2010). In any epistemological framework, reliability, and quality of inferences and constructs require an explicit description of how the empirical material was collected and all the operations performed in relation with the empirical material. The specific ways of building quality in data collection and analysis depend on the epistemological framework.

Generalization - also called external validity in the positivist and post-positivist frameworks refers to knowledge validity claims beyond the empirical basis upon which these knowledge claims have been elaborated. Qualitative research is often presented as more favorable than quantitative research for elaborating knowledge relevant for practice (Pratt, 2009). However, it is considered as suffering numerous weaknesses when it comes to justifying the validity of the knowledge claims (Pratt, 2009), particularly generalizations made on the basis of a single or even multiple case studies (Gibbert et al., 2008). Indeed, case study or small-N studies do not allow generalization from the characteristic of a sample to those of the corresponding population (in other terms, statistical generalization). However, as noted by numerous scholars (Tsoukas, 2011; Lee and Baskerville 2003; Tsang and Williams, 2012), generalization can take multiple forms. Lee and Baskerville (2003) identified four forms of generalization: from Empirical statement to Empirical statement (E/E), from Empirical statement to Theoretical statement (E/T), from Theoretical statement to Empirical statement $(\mathrm{T} / \mathrm{E})$, and from Theoretical statement to Theoretical statement $(\mathrm{T} / \mathrm{T})$. Two forms of generalization can be used by researchers doing case study, echoing Klein and Rowe (2008). 
First the results of a case study can be generalized by abstraction (type E/T generalization). In the positivist framework, the E/T generalization is also called analytical generalization (Yin, 2009). It aims at clarifying the theoretically necessary links between two or more characteristics of the phenomenon studied in the case. As we will see in more detail in the following section, generalization through abstraction for theory building can take different forms according to the epistemological framework considered (Tsoukas, 2011). Second, researchers can use case studies to generalize previous theory (type T/E generalization), applying theoretical concepts to different settings. As noted by Tsang and Williams (2012), this kind of generalization is closely related to empirical testing. According to the epistemological framework, this empirical testing can confirm or falsify insights in a replication logic or contribute to refining extant theory in an open-ended logic. In this later perspective, case studies offer "heuristic generalization opportunities for refining our analytical understanding of certain phenomena, namely opportunities for making more incisive distinctions than hitherto available" (Tsoukas, 2011: 295). This shows the strong links that connect generalization and the research project's main purpose, be it theorybuilding, theory-refinement or theory-testing.

\subsection{Conducting and justifying the quality of (post-) positivist case studies}

\subsubsection{Aim, design and mode of reasoning}

In positivism and post-positivism, there are various types of case study for generating or testing theory. The first type of case study is the one described by Eisenhardt $(1989,1991)$; we label this kind of method "exploratory inductive" because it aims at identifying surface patterns via inductive reasoning based upon multiple case studies, without specifically searching for underlying explanations of these patterns. The second type of case study is deductive and is mainly used to test theory (Dubé and Paré, 2003); thus we prefer labelling this type of method, which places a heavy emphasis on hypothesis testing (Yin, 2009), "deductive testing case study" rather than "explanatory case study" as proposed by Dubé and Paré (2003).

These two kinds of case studies combine within-case analysis with cross-case analysis. As such, they favor multiple-case design (Dubé and Paré, 2003). Within-case analysis serves to identify new concepts and/or new relations between concepts. Then, replication of the study to various different cases enables cross-case search for patterns (Eisenhardt, 1989, p. 540). The goal is to show that the new relations observed under certain conditions between concepts or categories in the first cases studied are also observed in the other cases under similar conditions. Hence, here, replication aims at verifying that the pattern initially identified holds across cases.

\subsubsection{Justifying the quality of "exploratory inductive" or "deductive testing" case studies}

Reliability means subsequent researchers will arrive at the same results if they conduct the study again, using the same steps. More precisely, reliability concerns phenomena measurement; measurement needs to be performed with instruments (measurement scales, questionnaires, etc.) that are reliable in the following sense: measuring the same phenomenon several times with the same instrument should yield the same results, independent of the person using the instrument.

The keywords are transparency and replication. The prerequisite for allowing transparency and replication is careful documentation and description of how the entire case study has been conducted. Two strategies are proposed to ensure reliability: the use of a case study protocol 
and the development of a case study database (Yin, 1989, 2009; Dubé and Paré, 2003; Gibbert et al., 2008). A case study protocol contains procedures and general rules that should be followed in using the diverse instruments (Dubé and Paré, 2003); combined with the data base, the case study protocol allows replication and increases measurement reliability.

Quality of inferences is related to the data analysis process; researchers have to provide a detailed description of the analytical procedures followed (Einsenhardt, 1989; Dubé and Paré, 2003). The key point is to maintain a logical chain of evidence that allows an external reviewer to follow the inferences made from raw material to ultimate case study conclusions (Yin, 1989, 2009; Dubé and Paré, 2003). Cross-coding aims at building analysis neutrality and objectivity and hence participates in building research reliability.

On one hand, construct quality depends on the formulation of a clear research framework. For instance, for a "deductive testing" case study, construct quality depends on whether theory triangulation - i.e. analyzing data from different theoretical perspectives (Yin, 2009) - has been performed; for an "exploratory inductive" case study, construct quality depends on whether a clear a priori specification of constructs - without specifying the relations between them - guides the study (Eisenhardt, 1989). On the other hand, construct quality refers to the capacity to build an accurate observation of the reality (Gibbert et al.,2008). In positivist and post-positivist epistemological frameworks, construct quality mainly depends on the quantity, precision, and variety of data collected. Several tactics are emphasized: multiple data collection, mix of qualitative and quantitative data, and data triangulation (Dubé and Paré, 2003; Gibbert et al., 2008).

Knowledge produced by case studies, more particularly "explorative inductive" ones, is generalized via abstraction (E/T generalization, also called analytical generalization). In analytical generalization, researchers aim at identifying the necessary theoretical links between two or more observable characteristics of the phenomena studied and specifying them in terms of a broader theoretical scheme (Tsoukas, 2011). However, in positivist and post-positivist frameworks, knowledge generalization is mainly performed with a replication slant, via empirical testing. Indeed, the principle of reproducibility plays a central role in this epistemological framework (Boisot and McKelvey, 2010). Since in the social sciences identical replication through experimentation is rarely possible, knowledge claims external validity testing is usually done via quantitative studies that aim at testing various theoretical hypotheses on samples representative of the population to which the knowledge claims have been generalized. Nevertheless, qualitative methods can be used to confirm or falsify theories such as in "deductive testing" case study. But in practice they are little used with this aim: according to Dubé and Paré (2003), it represents a mere 9\% of 183 positivist case studies published in seven major IS journals for the period 1990 through 1999. Indeed, concerning theory falsification, it can always be argued that as theories are simplifications, we are almost always able to find instances in which a theory does not hold precisely; thus the difficulty is to convince the reader that the case studied provides an important insight provoking the violation of the theory (Siggelkow, 2007).

\subsection{Conducting and justifying the quality of critical realist case studies}

\subsubsection{Aim, design and mode of reasoning}

In critical realism, research methods aim at developing, mainly via abductive reasoning (Mingers, 2004), specific conjectures on plausible generative mechanisms underlying the phenomena being investigated. Case study is thus presented as the best approach to exploring the interaction of structure, events, actions, and context in order to identify and formalize causal mechanisms (Wynn and Williams, 2012). We have labeled these kinds of methods "abductive explanatory" to differentiate them from "exploratory inductive methods" - which 
are concerned with directly observable surface relationships. Indeed, in abductive explanatory methods, researchers are principally interested in abductively finding explanations for the events observed.

Researchers can develop a single case study, mainly for theory building or a multiple case study for theory refinement. For instance, Tsoukas' (1989) abductive explanatory conception of comparative cases study - which differs from Eisenhardt's (1989) exploratory inductive one - aims at enriching the current view of generative mechanisms and of the manner in which they are activated, through a comparative analysis of different contextual conditions. In critical realism, comparative case studies shed light on the specific contingent conditions under which the postulated generative mechanisms combine and operate (Tsoukas, 1989).

\subsubsection{Justifying the quality of "abductive explanatory" case studies}

In contrast with case studies carried out in positivist and post-positivist frameworks, in critical realism, social phenomena are usually considered as shaped by humans who act intentionally and can learn. This renders difficult reliably measuring social phenomena. But this does not prevent scholars from attempting to understand the underlying reasons for their dynamics. Besides, social phenomena are considered as taking place within open systems whose artificial closure for experimentation purposes possibly generates important perturbations. This makes replication of social phenomena difficult (Bhaskar, 1998b).

In critical realism - as well as in pragmatic constructivism and interpretivism - the principle of reliability mainly concerns the cognitive path that leads from the empirical material through to the research results: researchers have to give readers the means to precisely follow the entire cognitive path (Schwartz-Shea, 2006; Charmaz, 2006). More precisely, researchers have to show how they have controlled and checked their interpretations throughout the research process, from formulating the research question through analyzing the data obtained and reporting the results (Sandberg, 2005). In particular, they have to explain the way the analysis - particularly the coding - was performed, as well as how the inferences were drawn. Quality of inferences refers to mapping out the pertinent configurational patterns of the phenomenon studied and trying to produce plausible explanations for the similarities and differences observed (Tsoukas, 1989). Similarities and differences are explained by a combination of generative mechanisms and types of contingencies that are responsible for their activation, involved in a particular setting. Building a data structure as proposed by Gioia et al. (2012) provides a graphic representation of how researchers progressed from raw data to terms and themes in conducting the analyses - a key component of demonstrating reliability and inferences quality.

Constructs consist of the structures, the generative mechanisms and the contextual conditions responsible for the observed patterns of events. As such, construct quality depends on the explanatory power of the model elaborated (Glaser, 2004). The explanation provided consists of the set of mechanisms which interact to generate the most accurate representation of the empirical world given our existing knowledge. Thus, it is possible and required to compare the explanatory power of the model elaborated to alternative theories (Wynn and Williams, 2012). Gioia et al. (2010) suggest that one of the researchers can play the role of the "devil's advocate" by offering alternative explanations for developing findings. Finally, as in the previous tradition, construct quality also depends on the quantity, precision, and variety of data collected. The collected data has to provide the detailed aspects of events being studied and a thick description of the structural entities, constituent parts, and contextual conditions existing in the case (Wynn and Williams, 2012). Data collection also involves asking the actors why the events under investigation have taken place (Tsoukas, 1989). 
In critical realism, generalization concerns the degree of abstraction of the explanatory model elaborated. In this approach, generality is not seen as a feature of the empirical domain but as a property of the necessary relations in structures operating in the real domain (Tsoukas, 2011). As such, "generalization does not come from a movement of empirical events in one context to empirical events in a novel context, but rather it results from the uncovering of the underlying essence of things, a movement from surface to depth" (Smith, 2006; p. 205). Thus, case studies are generalizable insofar as they provide an explanation of the causal powers which are at work and are capable of generating the observed phenomena (Tsoukas, 2011).

The abstract explanatory model produced via case studies can be relentlessly modified and enriched through testing it in qualitative research, permitting continual comparisons with more and more data (Glaser, 2004). Various methods can be used, such as comparative cases study (Tsoukas, 1989) and "design-oriented research" (Denyer et al., 2008; Pascal et al., 2013). This latter is used for testing prior knowledge claims, like those developed in evidence-based management. Such testing is performed within comparative cases studies rather than through replication, yet in a conception of scientific activity as "an ongoing irreducibly empirical open-ended process" (Bhaskar, 1998c, p xii). Nonetheless, since Tsang and Kwan's seminal work (1999), certain authors (Mingers, 2006; Miller and Tsang, 2010) have strived to develop methods aimed at enabling a form of replication that is more modest than in post-positivist frameworks. Indeed, in this epistemological framework, verification and falsification cannot be definitive. Failure to replicate prior knowledge claims regarding structures or generative mechanisms in another context does not constitute a falsification in Popper's sense, since this failure may be explained by contextual conditions or counterbalancing generative mechanisms (Tsang and Kwan, 1999).

\subsection{Conducting and justifying the quality of pragmatic constructivist case studies}

\subsubsection{Aim, design and mode of reasoning}

In pragmatic constructivism, knowledge generation aims at conceptualizing researchers' understanding of their flux of experience about the phenomena they investigate. More precisely researchers attempt to develop, particularly through abduction and conceptual assimilation (Glasersfeld, 2001), principles for organizing in an intelligible fashion the regularities they perceive in their flux of experience (Avenier and Parmentier Cajaiba, 2012). So, as in the case of critical realism, "abductive explanatory case studies" are the most appropriate kind of case studies in pragmatic constructivism. In practice, the main differences between knowledge developed in these two epistemological frameworks do not concern the knowledge process, but knowledge goals and status.

Indeed, as already indicated above ( $\$ 1.3$ and $\$ 2.3 .1)$, in critical realism knowledge aims at enriching the current views of generative mechanisms and the contingent conditions under which these generative mechanisms operate; the status of knowledge is one of correspondence regarding generative mechanisms and a pragmatic one regarding the manner generative mechanisms are activated. In pragmatic constructivism, knowledge aims at enriching the current understanding of researchers' flux of experiences in their contexts and the modelling of these understandings (Le Moigne, 2007). The status of knowledge is pragmatic in the sense that these understandings and modellings have to constitute viable markers for intentionally acting in situations of the sort that these understandings and modellings concern.

Consequently, in the next section we will not repeat the methodological arguments developed for the justification of "abductive explanatory case studies" carried out in critical realism that also hold in pragmatic constructivism. We solely focus on the way these methodological arguments need to be adapted or interpreted in pragmatic constructivism where required, as well as on methodological arguments hat are specific to this framework. 


\subsubsection{Specifically justifying the quality of "abductive explanatory case studies" in pragmatic constructivism}

The arguments developed in $\$ 2.3 .2$ for reliability justification in critical realism straightforwardly hold in pragmatic constructivism.

In pragmatic constructivism, the quality of inferences depends on the intelligibility and cogency of the reasoning used in building the model from the empirical material. For instance, in mapping out pertinent configurational patterns of the experience of the phenomenon studied, and trying to produce plausible explanations for the similarities and differences perceived. Perceived similarities and differences are explained by a combination of modelling principles and types of contextual conditions perceived to prevail in a particular setting. Showing a data structure as proposed by Gioia et al. (2012) helps justifying reliability and inferences quality.

In pragmatic constructivism, constructs consist of contextualized models elaborated on the basis of a number of extant modelling principles and theorizations. Construct quality depends on the model's functional fit in the context under consideration and viability for acting in this kind of context (Glasersfeld, 2001). Differently from critical realism, the mobilization of alternative theories serves to critically and knowledgeably enrich constructs (Le Moigne, 1990) - rather than compare their respective explanatory powers. Construct quality also depends on the richness of the empirical material gathered regarding the processes involved in the phenomenon under investigation, the context of this phenomenon, the possible individual and collective goals of the actors involved in it, and background information on the history of these processes, and of their contexts and goals (Le Moigne, 1990).

As in critical realism, generalization in pragmatic constructivism is conceptual: it goes from empirical material to abstract statements and models. Generalization is performed with the aim of intelligibly organizing flux of experiences in order to act intentionally in various kinds of contexts. The empirical testing of these statements and models is pragmatic. It is performed by examining whether, in another context, their re-contextualization according to specificities of the new context provides functionally fitted and viable insights for a goal-directed intervention in the new context (Avenier, 2010). When performed in case studies, this pragmatic empirical testing consists of examining whether the re-contextualized knowledge provides functionally fitted and viable markers for deciding and carrying out a goal-directed intervention in the situation under consideration (Avenier and Parmentier Cajaiba, 2012). This testing cannot be solely accomplished by researchers, even those acquainted with the setting, because knowledge activation in a particular setting demands local sense making and selfdesign by the practitioners involved in the goal-directed intervention (Tenkasi et al., 2007). As in critical realism, failure of the model to offer viable markers for acting in another context does not constitute a falsification in Popper's sense but a signal that further research needs to be carried out to understand the reasons for this failure (Avenier and Gavard-Perret, 2012). This can lead researchers to revise certain underlying principles and adapt the model accordingly.

\subsection{Conducting and justifying the quality of interpretivist case studies}

\subsubsection{Aim, design and mode of reasoning}

Interpretive research of a hermeneutic nature is the most diffused approach in interpretivist IS, Organization and Management research. So, in this paper, following Klein and Myers (1999) and Sandberg (2005), we focus on interpretivist case studies of a hermeneutic nature. These case studies aim at understanding the worlds of situational actors from their perspective, by describing how these actors make individual and collective sense of their particular world. Hence we name them "interpretive case studies". These kinds of case studies, among which 
we find the "natural inquiry" method (Lincoln and Guba, 1985), explicitly draw on various methodologies such as ethnomethodology (Garfinkel, 1967), hermeneutic methodology (Gadamer, 1976) and phenomenography (Marton, 1981).

These methods are usually conducted in unique case studies (Dyer and Wilkins, 1991; Sandberg, 2005). Researchers provide "thick descriptions" (Geertz, 1973; Schwartz-Shea, 2006) of the context in which the meaning-making and sense-making activities under investigation took place, and a narrative form of understanding based upon the beliefs and desires of actors (Bevir, 2006).

The main mode of reasoning in "interpretive descriptive case studies" is hermeneutic. Sometimes, these case studies also offer insights on how the processes of interpretation, meaning-making and engagement in situation possibly operate.

\subsubsection{Justifying the quality of "interpretive case studies"}

The following discussion is mainly based on Klein and Myers' (1999) and Sandberg's (2005) conceptions of research quality in interpretivism, which complement each other. Indeed Klein and Myers' (1999) keywords for characterizing research quality are plausibility and cogency, whereas Sandberg (2005) specifically discusses reliability and validity criteria. These criteria can appear more readily usable to certain researchers than Klein and Myers principles for improving the plausibility and cogency of interpretive accounts - even though, like Klein and Myers' (1999) principles, the use of these criteria requires considerable creative thinking.

First, we briefly recall Klein and Myers' seven principles. Then we show how Sandberg's criteria connect to these principles, which are as follows:

1. The principle of the hermeneutic circle suggests that all human understanding is achieved by iterating between considering the interdependent meaning of parts and the whole that they form. This principle of human understanding is fundamental to all the other principles.

2. The principle of contextualization requires that the subject matter be set in its social and historical context. It is noteworthy that the spirit in which this is done differs from a positivist account of history.

3. The principle of interaction between the researcher and the subjects requires critical reflection on how the research materials (or "data") were socially constructed through the interaction between the researchers and participants.

4. The principle of abstraction and generalization. Even though interpretive research is idiographic, intrinsic to interpretive research is the attempt to relate particulars to very abstract categories. This abstraction process is sometimes called "descriptive generalization" (Guba and Lincoln, 2007).

5. The principle of dialogical reasoning requires sensitivity to possible contradictions between the theoretical preconceptions guiding the research design and actual findings ("the story which the data tells") with subsequent cycles of revision.

6. The principle of multiple interpretations requires sensitivity to possible differences in interpretations among the participants.

7. The principle of suspicion requires critical thinking and "reading" the social world behind the words of the actors, a social world that is characterized by power structures, vested interests, and limited resources.

Sandberg's (2005) criteria are based upon the conception of truth as "intentional fulfillment" that holds in interpretivism. Intentional fulfillment means that there is agreement between the researcher's interpretation of the phenomenon being studied and the meaning given by research participants in lived experience. Sandberg (2005) views intentional fulfillment as a "truth constellation" that comprises various aspects that complement each other. He derives 
from this truth constellation three validity criteria to be used iteratively, namely communicative, pragmatic and transgressive validity criteria.

Communicative validity focuses on meaning coherence, stipulating that interpretations should be made coherent with the empirical material constituted and investigated. The principle of coherence is based upon the hermeneutic circle and requires implementing an iterative process where conflicting interpretations can be judged with respect to how coherent they are with the empirical material. Hence communicative validity is directly connected to Klein and Myers' (1999) principles 1, 2, 3 and 5.

Pragmatic validity addresses the issue of possible discrepancy between what people say they do and what they actually do. Building pragmatic validity involves searching for such possible discrepancy by asking follow-up questions that constantly embed the statements in concrete situations or through participant observation. Hence communicative validity is directly related to Klein and Myers' (1999) principles 6 and 7. Sandberg (2005) underscores that the most extensive way to check interpretations is testing them in practice, but this often requires a separate study in which the findings are re-contextualized into the practice being investigated. This view, which is not present in Klein and Myers' principles, brings Sandberg's conception of interpretivism closer to pragmatic constructivism than to Guba and Lincoln's (1989) interpretivism.

Transgressive validity draws the researcher's attention to possible irresolvable contradictions and tensions, which may be overlooked in the quest for communicative and pragmatic validity. Hence it is directly connected to Klein and Myers' principle 6. By systematically looking for differences and contradictions rather than coherence in lived experience, this criterion challenges and complements the criterion of communicative validity.

For Sandberg (2005), the principal question of reliability is about achieving interpretations truthful to lived experience where truth is conceived as intentional fulfillment. Given this conception of truth, criteria of reliability, such as replicability and interjudge reliability of results relating to objective reality, fall outside the domain of interest in achieving reliability within interpretivist approaches. Instead, the proposed truth constellation implies first and foremost that researchers must show how they controlled and checked their interpretations throughout the research process, i.e. how they dealt with their subjectivity. Acknowledging subjectivity does not mean accepting 'biased subjectivity' that occurs for instance when one principally takes note of statements that support one's opinions, selectively interprets statements so one can justify one's own conclusions, and tends to ignore counter evidence.

To sum up, Klein and Myers' (1999) principles for interpetivist case study quality and Sandberg's (2005) reliability and validity criteria are mutually consistent. They also complement each other. Indeed, Klein and Myers highlight abstraction and descriptive generalization, whereas Sandberg precisely specifies the notion of reliability in interpretivist research, and highlights the importance of "thick descriptions" (Geertz, 1973) and treating all the aspects of the lived experience under investigation as equally important - in particular, giving equal voice to all individuals involved. In addition, Sandberg (2005) suggests the possibility of pragmatically testing descriptive generalizations, which is fairly unusual in interpretivist guidelines and situates his conception of interpretivist research closer to pragmatic constructivist research than most other conceptions.

\subsubsection{Focus on interpretivist critical case studies}

Because of the particular relevance critical research has in IS research, we think it is important to briefly discuss critical case studies. One difficulty is that of substantial diversity within the critical research philosophy; there is no single coherent theoretical foundation (Myers and Klein, 2011). However, all critical studies share two characteristics: they rely on a strong theoretical base that includes taking a value position and a critical stance towards the 
way things are, and they offer suggestions on the way things could be that would bring improvements to society (Myers and Klein, 2011). Since critical research shows similarities with interpretivist research (Orlikowski and Baroudi, 1991), concentrating on critical case studies conducted in the framework of interpretivism makes sense and permits one to develop a fairly consistent view of these kinds of case studies. Hence, in this section we focus on the specific principles and criteria for quality of interpretivist critical case studies which apply beyond the generic ones that apply for interpretivist case studies in general - which were discussed in the previous section.

The two features evoked above that are specific to critical studies have several consequences on the research design of critical interpretivist case studies. Particularly, data collection and analysis are organized around core concepts from critical social theorists; and researchers subject the value position they take to continual critical reflection, as well as the concept they mobilize. In particular researchers engage in challenging prevailing assumptions, beliefs, values and practices that are often taken for granted, with potentially conflicting arguments and evidence. The special features of critical case studies also condition the kind of knowledge that is generated, namely knowledge oriented toward facilitating the realization of human needs and potential, critical self-reflection and associated self-transformation, i.e. fostering participants' reflexivity (Rowe, 2009), as well as individual emancipation, improvements in society and in social theories (Myers and Klein, 2011). In other words, the knowledge generated is not limited to interpretive descriptions. It also suggests how things could be, given the constraints associated with the current circumstances - for instance how unwarranted uses of power might be overcome (Myers and Klein, 2011).

Myers and Klein (2011) underscore that although data collection and analysis are supposed to be organized around the core concepts from one or more critical social theorists, this does not mean that these concepts should remain unchallenged or that new ones might not emerge. Rather, the theoretical apparatus mobilized should be subject to change, partly in response to new historical discoveries or empirical data on current social changes, and partly in response to new theoretical reasoning and debate. Indeed, critical theorists believe that our theories are fallible and that improvements in social theories are possible through critique and debate. Theory testing is accomplished in critical case studies through the use of theory as a "sensitizing device" to view the world in a certain way (Myers and Klein, 2011). Differently from the situation in pragmatic constructivist case studies, the social transformations and the emancipatory actions suggested in a critical case study do not constitute a means to pragmatically test the knowledge that has been generated in the study. These transformative actions are ends in themselves. All this suggests that in IS especially, some critical research should be seeking to improve socio-technical theory (Myers and Klein, 2011).

\subsection{Synthesis Table}

Table 2 synthesizes the insights offered throughout $\$ 2$ on how to design and conduct rigorous case studies within each of the four epistemological frameworks considered in the article. The column "Interpretivism" also highlights specific quality principles of interpretivist critical case studies, which apply beyond those refering to interpretivist case studies in general. 
Table 2: Case study quality justification in the various epistemological frameworks

\begin{tabular}{|c|c|c|c|c|c|}
\hline & $\begin{array}{l}\text { Positivism and Post- } \\
\text { positivism }\end{array}$ & Critical realism & $\begin{array}{c}\text { Pragmatic } \\
\text { constructivism }\end{array}$ & \multicolumn{2}{|c|}{ Interpretivism } \\
\hline $\begin{array}{l}\text { Types of case } \\
\text { studies }\end{array}$ & $\begin{array}{l}\text { Exploratory inductive case } \\
\text { studies, or deductive testing } \\
\text { case studies }\end{array}$ & $\begin{array}{l}\text { Abductive explanatory case } \\
\text { studies }\end{array}$ & $\begin{array}{l}\text { Abductive explanatory case } \\
\text { studies }\end{array}$ & Interpretive case studies & $\begin{array}{l}\text { Interpretivist critical case } \\
\text { studies }\end{array}$ \\
\hline $\begin{array}{l}\text { Prerequisite of } \\
\text { quality }\end{array}$ & \multicolumn{5}{|c|}{$\begin{array}{l}\text { Explicit description of how the empirical material was collected and all the operations performed in relation with the empirical material. } \\
\text { The specific ways of performing data collection and analysis depend on the epistemological framework. }\end{array}$} \\
\hline Reliability & $\begin{array}{l}\text { Transparency, replication } \\
\text { and measurement reliability } \\
\text { based on a case study } \\
\text { protocol and a case study } \\
\text { database. } \\
\text { Cross coding participates in } \\
\text { building analysis' neutrality } \\
\text { and objectivity, and thus } \\
\text { research reliability. }\end{array}$ & $\begin{array}{l}\text { Intelligibility and cogency of } \\
\text { the cognitive path: provide an } \\
\text { explicit description of how } \\
\text { researchers progress from raw } \\
\text { data to terms and themes in } \\
\text { conducting the analyses, as in } \\
\text { Gioia et al.'s (2012) method. }\end{array}$ & $\begin{array}{l}\text { Intelligibility and cogency of } \\
\text { the cognitive path: provide an } \\
\text { explicit description of how } \\
\text { researchers progress from raw } \\
\text { material to the knowledge } \\
\text { elaborated, as in Strauss \& } \\
\text { Corbin (1990) or Gioia et al. } \\
\text { (2012). }\end{array}$ & $\begin{array}{l}\text { Truthfulness, Trustwortl } \\
\text { Thick descriptions } \\
\text { Showing how interpreta } \\
\text { were controlled and } \\
\text { research process. } \\
\end{array}$ & $\begin{array}{l}\text { hiness, Credibility } \\
\text { ations of empirical material } \\
\text { checked throughout the }\end{array}$ \\
\hline \multirow[t]{2}{*}{$\begin{array}{l}\text { Inferences } \\
\text { quality }\end{array}$} & \multirow[t]{2}{*}{$\begin{array}{l}\text { Elucidation of the analytical } \\
\text { procedures followed. } \\
\text { Maintaining a chain of } \\
\text { evidence from raw data to } \\
\text { ultimate conclusions. }\end{array}$} & \multirow[t]{2}{*}{$\begin{array}{l}\text { Quality of inferences is related } \\
\text { to producing plausible } \\
\text { explanations for the similarities } \\
\text { and differences observed. }\end{array}$} & \multirow[t]{2}{*}{$\begin{array}{l}\text { Quality of inferences depends } \\
\text { on the intelligibility and } \\
\text { cogency of the reasoning used } \\
\text { in building the model from the } \\
\text { empirical material. }\end{array}$} & \multicolumn{2}{|c|}{$\begin{array}{l}\text { Quality of inferences is evaluated in terms of the } \\
\text { plausibility and cogency of the logical reasoning } \\
\text { used in describing the research process and how } \\
\text { conclusions were drawn from the empirical } \\
\text { material, particularly showing how the hermeneutic } \\
\text { circle was used. }\end{array}$} \\
\hline & & & & & $\begin{array}{l}\text { Consistency of the } \\
\text { inferences with the value } \\
\text { position taken. }\end{array}$ \\
\hline $\begin{array}{l}\text { Construct } \\
\text { quality }\end{array}$ & $\begin{array}{l}\text { Construct quality depends } \\
\text { on the formulation of a clear } \\
\text { research framework and the } \\
\text { quantity, precision, and } \\
\text { variety of data collected } \\
\text { (multiple data collection, } \\
\text { mix of qualitative and } \\
\text { quantitative data, and data } \\
\text { triangulation). }\end{array}$ & $\begin{array}{l}\text { Construct quality depends on } \\
\text { the explanatory power of the } \\
\text { model elaborated, generating } \\
\text { the most accurate explanation } \\
\text { of the empirical world given our } \\
\text { existing knowledge. } \\
\text { It also depends on the quantity, } \\
\text { precision, and variety of data } \\
\text { collected on events, social } \\
\text { structures, contextual conditions } \\
\text { and actors accounts of the } \\
\text { reasons why the events under } \\
\text { investigation have taken place. }\end{array}$ & $\begin{array}{l}\text { Construct quality depends on } \\
\text { the richness of the empirical } \\
\text { material constituted as well as } \\
\text { on the model's functional fit in } \\
\text { the context under consideration } \\
\text { and on its viability for acting in } \\
\text { this context. } \\
\text { Reflective critique }\end{array}$ & $\begin{array}{l}\text { Construct quality } \\
1 \text { depends on the } \\
\text { communicative, and } \\
\text { pragmatic } \\
\text { transgressive validity } \\
\text { of interpretations. } \\
\text { Equal voice needs to } \\
\text { be given to all actors } \\
\text { concerned by the } \\
\text { study. } \\
\text { Reflexivity }\end{array}$ & $\begin{array}{l}\text { Construct quality depends } \\
\text { on the organization of } \\
\text { data collection and } \\
\text { analysis around core } \\
\text { concepts from critical } \\
\text { social theorists as well as } \\
\text { on bringing to light } \\
\text { inconsistent and even } \\
\text { conflicting findings. } \\
\text { Voice to be given parti- } \\
\text { cularly to marginalized or } \\
\text { disadvantaged groups. }\end{array}$ \\
\hline $\begin{array}{l}\text { Theoretical } \\
\text { contribution }\end{array}$ & $\begin{array}{l}\text { Theory building } \\
\text { Theory testing }\end{array}$ & $\begin{array}{l}\text { Theory building } \\
\text { Theory refinement }\end{array}$ & $\begin{array}{l}\text { Theory building } \\
\text { Theory refinement }\end{array}$ & $\begin{array}{l}\text { Theory building } \\
\text { Theory refinement }\end{array}$ & \begin{tabular}{|l|} 
Theory building \\
Theory refinement
\end{tabular} \\
\hline
\end{tabular}




\begin{tabular}{|c|c|c|c|c|c|}
\hline $\begin{array}{l}\text { Generalization } \\
\text { Mode }\end{array}$ & $\begin{array}{l}\text { Generalization via } \\
\text { abstraction: analytical } \\
\text { generalization for } \\
\text { "exploratory inductive" case } \\
\text { study. } \\
\text { Generalization consists of } \\
\text { identifying and clarifying } \\
\text { the necessary theoretical } \\
\text { links between two or more } \\
\text { observable characteristics of } \\
\text { the phenomenon studied. }\end{array}$ & $\begin{array}{l}\text { Generalization via abstraction. } \\
\text { Generalization results from the } \\
\text { uncovering of the underlying } \\
\text { essence of things, a movement } \\
\text { from surface to depth. }\end{array}$ & $\begin{array}{l}\text { Generalization via abstraction. } \\
\text { Generalization is driven by the } \\
\text { aim of intelligibly bringing flux } \\
\text { of experiences into a logical } \\
\text { order to offer heuristic markers } \\
\text { for intentionally acting in } \\
\text { various kinds of contexts. }\end{array}$ & $\begin{array}{l}\text { Descriptive } \\
\text { generalization. } \\
\text { Possible conceptual } \\
\text { generalizations via } \\
\text { abstraction. }\end{array}$ & $\begin{array}{l}\text { Conceptual generalization } \\
\text { via abstraction for } \\
\text { developing or improving } \\
\text { social theories. }\end{array}$ \\
\hline Future testing & $\begin{array}{l}\text { Confirmation or falsification } \\
\text { via "deductive testing" case } \\
\text { studies and mainly via } \\
\text { quantitative } \\
\text { studies. } \\
\text { Emphasizing the replication } \\
\text { logic. }\end{array}$ & $\begin{array}{l}\text { Testing of the Generative } \\
\text { Mechanisms' activation in the } \\
\text { empirical field can be } \\
\text { pragmatically performed in } \\
\text { qualitative studies (theory } \\
\text { refinement) and/or via } \\
\text { quantitative methods (theory } \\
\text { testing). }\end{array}$ & $\begin{array}{l}\text { Pragmatic testing of } \\
\text { knowledge's functional fit and } \\
\text { viability for intentionally acting } \\
\text { in the kind of situations } \\
\text { investigated. } \\
\text { Testing carried out in } \\
\text { qualitative studies, particularly } \\
\text { in design research and action } \\
\text { research. }\end{array}$ & 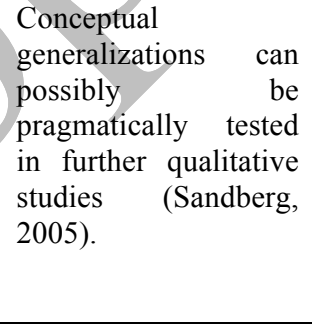 & $\begin{array}{l}\text { Testing through critique } \\
\text { and debate in subsequent } \\
\text { critical case studies or } \\
\text { action research. }\end{array}$ \\
\hline $\begin{array}{l}\text { Examples of } \\
\text { methodological } \\
\text { guidelines }\end{array}$ & $\begin{array}{l}\text { Eisenhardt, 1989, 1991; Yin, } \\
\text { 1989, 2009; Dubé \& Paré, } \\
2003 \\
\text { Gibbert et al., 2008. }\end{array}$ & $\begin{array}{l}\text { Tsoukas, 1989; } \\
\text { Williams, } 2012 .\end{array}$ & $\begin{array}{l}\text { Goldkuhl, 2008, 2012; Avenier } \\
\text { \& Parmentier Cajaiba, 2012; } \\
\text { Parmentier Cajaiba \& Avenier, } \\
\text { 2013; Albert \& Couture, 2014. }\end{array}$ & $\begin{array}{lr}\text { Dyer \& } & \text { Wilkins, } \\
\text { 1991; Klein \& Myers, } \\
\text { 1999; } \\
2005 .\end{array}$ & Myers \& Klein, 2011. \\
\hline $\begin{array}{l}\text { Examples of case } \\
\text { studies }\end{array}$ & $\begin{array}{l}\text { Markus, 1983; Pinsonneault } \\
\text { \& Kraemer, 1993; Ozcan \& } \\
\text { Eisenhardt, 2009; Bingham } \\
\text { \& Eisenhardt, 2011. }\end{array}$ & $\begin{array}{l}\text { Stigliani I., Ravasi D., } 2012 . \\
\text { Williams \& Karahanna, } 2013 . \\
\text { Pascal et al., } 2013^{3}\end{array}$ & $\begin{array}{l}\text { Albert \& Couture, 2013; } \\
\text { Mazmanian et al., 2014. } \\
\text { Lindgren et al., 2004 }\end{array}$ & $\begin{array}{l}\text { Sandberg, } 2000 ; \\
\text { Cope, } 2011 .\end{array}$ & $\begin{array}{l}\text { Young, Kuo \& Myers } \\
\text { 2012; Ravishankar, Pan \& } \\
\text { Myers, 2013. }\end{array}$ \\
\hline
\end{tabular}

\footnotetext{
${ }^{3,4}$ The examples of design research (Pascal et al.,2014) and action research (Lindgren et al., 2004) - which are not examples of case study research stricto sensu - are cited to illustrate ways for pragmatically testing knowledge respectively in critical realism and in pragmatic constructivism discussed in this paper.
} 


\section{Discussion}

This discussion is organized around three main points. First, we highlight the commonalities and differences between quality principles in two epistemological frameworks that are located in the epistemic transition zone (Johnson et al., 2006), namely critical realism and pragmatic constructivism. Then we discuss the importance of explicitly inscribing any single research project in an epistemological framework, and, in the third point, argue that the multiplicity of epistemological frameworks mobilized in the disciplines considered in this article provides richness to each of these disciplines.

\subsection{Main commonalities and differences between critical realism and pragmatic constructivism}

In this paper we have considered four epistemological traditions: positivism and postpositivism, critical realism, pragmatic constructivism, and interpretivism. This classification has two main advantages. First, it combines the various possible combinations between ontological realism vs. ontological relativism (OR vs. ORel) on the one hand, and epistemic realism vs. epistemic relativism (ER vs. ERel) on the other one. Indeed, positivism and postpositivism posit (OR / ER) critical realism (OR/ ERel), pragmatic constructivism (- / ERel) and interpretivism (ORel / ERel), and the combination of ontological relativism with epistemic realism does not make sense. Secondly, this classification takes into account two growing epistemological traditions that occupy an intermediary position between positivism and interpretivism: critical realism and pragmatic constructivism. To further understand these two traditions located in the epistemological transition zone (Johnson et al., 2006), we wish to emphasize their main commonalities and differences.

As seen before, critical realism posits a realist ontology based on a stratified conception of reality and at the same time, accepts the relativism of knowledge. Pragmatic constructivism has the following property: for the sake of framing a particular research project conducted in this epistemological framework, scholars have the possibility of taking any beliefs concerning the possible nature of the world (that are consistent with their experience of that world) as working assumptions, particularly the critical realist ones or the interpretivist ones. The only condition is to explicitly state these working assumptions at the start of the project, define a research design consistent with them, and recall them when presenting the research results (Avenier, 2010). This opening creates possible overlaps between research done in pragmatic constructivism and critical realism or interpretivism.

As highlighted by Table 2, the methods for knowledge generation and for empirically testing generalizations appear fairly similar in critical realism and pragmatic constructivism. However, even though knowledge claims can be developed with similar methods, the differences in these frameworks' ontological founding assumptions induce differences in the status of knowledge in these two frameworks. In critical realism, knowledge aims at describing the (postulated) deep reality as-is, and hence concerns ontology: knowledge developed about generative mechanisms is supposed to describe how these (postulated) generative mechanisms function in various contexts. The higher the conceptual level of knowledge about generative mechanisms, the deeper the level of reality these generative mechanisms represent. In pragmatic constructivism, conceptual knowledge does not pretend to provide an iconic description of whatever possibly exists; rather it aims at offering intelligible and functionally fitted models to viably deal with the world of experience. Hence it concerns flux of experiences rather than ontology.

This difference in knowledge status induces important differences in the way knowledge can be used in practice. Since the knowledge developed in critical realism is supposed to provide 
plausible explanations of how the world functions, it offers solidly-argued grounds upon which to make decisions for intervening adequately in a situation, taking into account the role of the contexts in generative mechanisms' activation. Thus, the knowledge developed in critical realism does not provide law-like rules but heuristic propositions based upon the explanatory power of generative mechanisms. In pragmatic constructivism, knowledge does not pretend to provide descriptions of how the world functions, but functionally fitted and viable models for dealing with the world of experience. These models are to be used as heuristic markers supporting open reflections and discussions on how to adequately intervene in a situation.

\subsection{The importance of explicitly inscribing any single research project in an epistemological framework}

In this paper, we have shown that the goal of theory-building and the form of research results depend on the research's epistemological framework, and that the validity of research results can only be justified in reference to a certain vision of what is knowledge, i.e. in reference to an epistemological framework. So, in this respect, our contribution is in agreement with a number of authors' views, such as Klein and Myers (1999), Gephart (2004), Sandberg (2005), Johnson et al. (2006), Amis and Silk (2008) and Easterby-Smith et al. (2008), as well as with those of Morgan and Smircich (1980), Cunliffe (2011) and Keutel et al. (2014). We supplement these authors' works in two ways: (1) we consider various epistemological frameworks that are not discussed in the classifications that they use; (2) for every epistemological framework considered in the current paper, we exhibit some key markers to help researchers rigorously conduct case study research.

In the main body of the paper, we have argued that the validity of research results depends on the fit between the method effectively implemented and the research project's epistemological framework. However, we highlighted that the relationship between kind of research method and kind of epistemological framework is not a one-to-one relationship. For instance, as seen above, case study can be used to generate knowledge in very different epistemological frameworks. But when researchers want to mobilize this kind of method, they have to implement it in fairly different ways, depending on the epistemological framework of the research project. Providing researchers with this crucial information and explanations would considerably help them to make sound methodological decisions and furthermore, foster overall improvement of quality of qualitative research in a pluralistic field. As such, we participate in increasing authors' as well as reviewers' general understanding of different epistemological traditions. This considerably helps authors locate and make explicit their own underlying philosophical assumptions and be informed as to how case studies ought to be shaped and judged depending on the tradition to which they subscribe (Easterby-Smith et al., 2008; Keutel et al., 2014). Therefore, the proposed contingent "criteriology" (Johnson et al., 2006) synthetized in Table 2 constitutes a heuristic device to critically and knowledgeably use case study within different epistemological traditions, echoing Mingers (2001) recommendations.

From this perspective, this article provides some guidelines for increasing methodological diversity particularly in doing case study, but not at the expense of rigor. Indeed, a deep understanding of the quality criteria corresponding to the epistemological tradition in which the research is conducted allows researchers to mindfully explore different possible design alternatives and to sometimes try new designs in order to capture the most of this research strategy's potential (Keutel et al., 2014). 


\subsection{The multiplicity of epistemological frameworks as a richness for the disciplines}

Even though we have just argued that it is essential to inscribe any single research project in an explicit epistemological framework, and even though any individual researcher probably feels more inclined to inscribe their research projects in a particular epistemological framework and use a particular research method, this does not mean that we consider that any of the disciplines of IS, Organization, and Management sciences should subscribe to one and only one epistemological framework.

On the contrary, along with numerous scholars (e.g. Myers and Klein, 2011, and Hassan, 2014 in the IS field), we consider that pluralism is essential in these disciplines. Indeed, "pluralism is not problematic; quite the opposite, it speaks to the very vitality of the field of organizational studies" (Amis and Silk, 2008, p. 475). Pluralism in philosophical, theoretical and methodological positions is a great asset to these disciplines (Romme et al., 2015, forthcoming). "Using different theory-building approaches to study disparate issues is a better way of fostering more comprehensive portraits of complex organizational phenomena" (Gioia and Pitre, 1990).

Gioia and Pitre's (1990) notion of meta-paradigm perspective amounts to considering that Mingers's (2001) view according to which methods can be detached from the epistemological frameworks in which they have initially been developed, and critically and knowledgeably used within a context that makes different assumptions, also applies to the use of knowledge itself. This means that in any research project, it may be possible to integrate elements developed in another epistemological framework, albeit not in an arbitrary manner (Myers and Klein, 2011), but critically and knowledgeably - i.e. by reinterpreting them according to the founding assumptions of the epistemological framework in which knowledge integration takes place. Indeed, any meta-paradigm perspective is nonetheless rooted in a specific paradigm, that to which the researcher subscribes (Gioia and Pitre, 1990).

This is precisely what Denyer et al. (2008) propose to do for developing design propositions through research synthesis in a critical realist framework. In the same spirit, Romme and Van Burg (2014) offer a critical realism-affiliated methodological framework for research synthesis in entrepreneurship which fosters reflectively integrating knowledge developed in positivist, interpretive, and pragmatic epistemological frameworks.

\section{Conclusion}

The expanding popularity of qualitative research, and more particularly case study, in the field of Information Systems, Organization and Management research, seems to have been accompanied by an increasing divergence in the forms that it takes (Johnson et al., 2006). In this paper we have developed a heuristic framework for guiding the design of a rigorous case study depending on the research's goal and epistemological framework. This framework can also provide guidance to reviewers in their evaluations. We have also highlighted the fundamental reasons - namely the epistemological ones - for differences in the guidelines offered in the literature for conducting high quality case studies. As such, we propose a set of contingent criteria to be used as a heuristic device to critically and knowledgeably build rigorous case studies within different epistemological traditions following Mingers' (2001) recommendations. In line with Keutel et al. (2014) we argue for more mindfulness regarding the design and accomplishment of case studies.

Naturally, we recognize that evaluation criteria are historically and socially constructed philosophical conventions. Especially, they express competing justificatory logics to control the discipline's formal evaluation system, determining what constitutes valid knowledge (Sandberg, 2005). Nevertheless, identifying these conventions and rendering them explicit is crucial to understanding how to legitimize a particular research project in a certain epistemological framework, to critically and knowledgeably use methods (Mingers, 2001), 
and to suggest the use of specific evaluation criteria (Johnson et al., 2006). Moreover, embracing and articulating different sets of epistemological assumptions could function as a means of communication between schools of thought, and may serve to empower mutual understanding through dialogue with, and receptiveness to the philosophical assumptions of others (Easterby-Smith et al., 2008).

Last but not least, this study has important implications for research practice. First, from the very start of a research project, specify its epistemological framework. We have emphasized that underlying any form of research there is a philosophy of knowledge - otherwise known as an epistemological framework. However, the underlying philosophy of knowledge remains more often implicit than explicit. Nowadays, since various solidly-argued epistemological frameworks are available, it is important to choose one deliberately when undertaking research, rather than to inherit one by default (Van de Ven, 2007). Second, researchers need to be mindful to maintain the internal consistency of the research design, particularly consistency between the epistemological framework, the goal of research (namely, theory building, theory refinement or theory testing) and the implemented method. Finally, it is advisable to focus submissions on academic journals open to the research epistemological framework in question.

\section{Acknowledgments}

This article is the result of a thoroughly collaborative co-authoring process. We gratefully acknowledge the helpful comments of the participants in the 2013 AIMS Conference, 2013 EURAM Conference and 2014 AIM Conference. We are especially thankful to SIM Editor in Chief, Régis Meissonier, and to our two anonymous reviewers for the valuable comments and suggestions they provided during the review process. Marie-José Avenier gratefully acknowledges that this research was conducted within the "Management stratégique des PMI et ETI de service aux entreprises" program under the aegis of the Europlace Institut of Finance, a joint initiative by Beauvais International.

\section{References}

Ågerfalk, P.J. (2010), “Getting pragmatic", European Journal of Information Systems, vol. 19 , p. 251-256.

Ågerfalk, P.J. (2014), "Insufficient Theoretical Contribution: a Conclusive Rationale for Rejection?”, European Journal of Information Systems, vol. 23, ㅇ, p. 593-599.

Albert, M.-N., Couture, M.-M. (2013), “The Support to an Entrepreneur: From Autonomy to

Dependence", SAGE Open, 3, Published 13 June 2013, http://sgo.sagepub.com/content/3/2/2158244013492779.

Albert, M.-N., Couture, M.-M. (2014), “To Explore New Avenues: Experiential Testimonio Research", Management Decision, vol. 52, n 4, p. 794-812.

Amis, J. M., Silk, M. L. (2008), "The Philosophy and Politics of Quality in Qualitative Organizational Research", Organizational Research Methods, vol. 11, n 3, p. 456-480.

Avenier, M.J. (2010), "Shaping a Constructivist View of Organizational Design Science", Organization Studies, $\mathrm{n}^{\circ}$ 31, p. 1229-1251.

Avenier, M.J. (2011), "Les paradigmes épistémologiques constructivistes : postmodernisme ou pragmatisme? ", Management \& Avenir, n 43, p. 371-390.

Avenier, M.J., Gavard-Perret, M-L. (2012), "Inscrire son projet de recherche dans un cadre épistémologique", in Gavard-Perret M-L., Gotteland, D., Haon, C., Jolibert A. [eds.], Méthodologie de la recherche en sciences de gestion - Réussir son mémoire ou sa thèse, 2è édit, Paris, Pearson Education France, p. 11-62.

Avenier, M.J., Parmentier Cajaiba, A. (2012), “The Dialogical Model: Developing Academic Knowledge for and from Practice", European Management Review, vol. 9, n 4, p. 199-212. 
Avison, D., Malaurent, J. (2013), "Qualitative Research in Three IS Journals: Unequal Emphasis but Common Rigour, Depth and Richness", Systèmes d'Information et Management, décembre, vol. 18, $\mathrm{n}^{\circ}$ 4, p. 75-123.

Baskerville, R., Pries-Heje, J. (1999), "Grounded Action Research: A Method for Understanding IT in Practice", Accounting, Management and Information Technology, vol. $9, \mathrm{n}^{\circ} 1, \mathrm{p} .1-23$

Bevir, M. (2006), "How Narratives Explain". In D. Yanow and P. Schwartz-Shea (eds), Interpretation and Method: Empirical Research Methods and the Interpretive Turn, M.E. Sharpe, Armonk, NY, p. 281-290.

Bhaskar, R. (1978), “A Realist Theory of Science”, Harvester Press, Hassocks, England.

Bhaskar, R. (1998a), "General Introduction", in Critical Realism Essential Readings, M. Archer, R. Bhaskar, A. Collier, T. Lawson, and A. Norrie (eds), Routledge, New York, p. ixxxiv

Bhaskar, R. (1998b), "Philosophy and Scientific Realism", in Critical Realism Essential Readings, M. Archer, R. Bhaskar, A. Collier, T. Lawson, and A. Norrie (eds), Routledge, New York, p. 16-47.

Bhaskar, R. (1998c), "The Logic of Scientific Discovery", in M. Archer, R. Bhaskar, A. Collier, T. Lawson, A. Norrie (eds), Critical Realism Essential Readings, Routledge, New York, p. 48-103.

Bhaskar, Roy (1998d), "Societies" in Critical Realism Essential Readings, M. Archer, R. Bhaskar, A. Collier, T. Lawson, and A. Norrie (eds), Routledge, New York, p. 206-257.

Bingham, C.B., Eisenhardt, K.M. (2011), "Rational Heuristics: The "Simple Rules" that Strategists Learn from Process Experience", Strategic Management Journal, vol. 32, p. 1437-1464.

Boisot, M., McKelvey, B. (2010), "Integrating Modernist and Postmodernist Perspectives on Organizations: A Complexity Science Bridge", Academy of Management Review, vol. 35, n³, p. 415-433.

Carlsson, S. A. (2007), "Developing Knowledge Through IS Design Science Research", Scandinavian Journal of Information Systems, vol. 19, $\mathrm{n}^{\circ}$ 2, p. 75-86.

Charmaz, C. (2006), "Constructing Grounded Theory: A Practical Guide through Qualitative Analysis", Sage, London.

Cope, J. (2011), Entrepreneurial Learning from Failure: An Interpretative Phenomenological Analysis, Journal of Business Venturing, vol. 26, p. 604-623.

Cunliffe, A. L., (2011), "Crafting Qualitative Research: Morgan, Gareth and Smircich, Linda 30 years on", Organizational Research Methods, vol. 14, n 4, p. 647-673.

Davison, R. M., Martinsons, M. G., Ou, C. X.J. (2012), "The Roles of Theory in Canonical Action Research", MIS Quarterly, vol. 36, n 3, p.763-786.

Denyer, D., Tranfield, D., Van Aken, J. (2008), "Developing Design Propositions through Research Synthesis", Organization Studies, vol. 29, n 3, p. 393-413.

Denzin, N. K., Lincoln, Y. S. (2003a), "Collecting and Interpreting Qualitative Materials", Sage, London.

Denzin, N. K., Lincoln, Y. S. (2003b), "Strategies of Qualitative Inquiry”, Sage, London.

De Vaujany, F-X. (2008), "Capturing Reflexivity Modes in IS: A Critical Realist Approach", Information and Organization, $\mathrm{n}^{\circ} 18$, p. 51-72.

Dewey, J. (1938), "Logic: the Theory of Inquiry", Henry Holt, New York.

Dubé, L., Paré, G. (2003), "Rigor in Information Systems Positivist Case Research: Current Practices, Trends, and Recommendations", MIS Quarterly, vol. 27, n 4, p. 597-635.

Dyer, G. W., Wilkins, A. L. (1991), "Better Stories, Not Better Constructs to Generate Better Theory: A Rejoinder to Eisenhardt", Academy of Management Review, vol. 16, n³, p. 613619. 
Easterby-Smith, M., Golden-Biddle, K. and Locke, K. (2008) "Working with Pluralism: Determining Quality in Qualitative Research", Organizational Research Methods, vol. 11, $\mathrm{n}^{\circ} 3$, p. 419-429.

Eisenhardt, K. M. (1989), "Building Theories from Case Study Research", Academy of Management Review, $\mathrm{n}^{\circ}$ 14: 532-550.

Eisenhardt, K. M. (1991), "Better Stories and Better Constructs: The Case for Rigor and Comparative Logic", Academy of Management Review, vol. 16, p. 620-627.

Gadamer, H-G. (1976), "Philosophical Hermeneutics", UC Press, Berkeley.

Garfinkel, H. (1967), "Studies in ethnomethodology", Prentice-Hall, New York.

Geertz, C. (1973), "Interpretation of Cultures: Selected Essays", Basic Books, New York .

Gephart, R. P. Jr (2004), "From the Editors: Qualitative Research and the Academy of Management Journal”, Academy of Management Journal, vol. 47, n 4, p. 454-462.

Gephart, R. P. Jr (2013), "Doing Research with Words: Qualitative Methodologies and Industrial/Organizational Psychology", in Modern Research Methods for the Study of Behavior in Organizations, J. M. Cortina and R. S. Landis [eds.], Routledge, New York, p. 265-317.

Gibbert, M., Ruigrok, W., Wicki, B. (2008), "Research Notes and Commentaries: What Passes as a Rigorous Case Study?", Strategic Management Journal, vol. 29, p. 1465-1474.

Gioia, D. A., Pitre, E. (1990), "Multiparadigm Perspectives on Theory Building", Academy of Management review, vol. 15, $\mathrm{n}^{\circ} 4$, p. 584-602.

Gioia, D. A., Price, K. N., Hamilton, A. L., Thomas, J B. (2010), "Forging an Identity: An Insider-outsider Study of Processes Involved in the Formation of Organizational Identity", Administrative Science Quarterly, vol. 55, p. 1-46.

Gioia, D. A., Corley, K. G., Hamilton, A. L. (2012), "Seeking Qualitative Rigor in Inductive Research: Notes on the Gioia Methodology", Organizational Research Methods, published on line http://orm.sagepub.com/, p. 1-17.

Glaser, B. G. (2004) "Naturalist Inquiry and Grounded Theory, Forum Qualitative Social Research", vol. 5, n 1 , Art.7

Glaser, B. G., Strauss, A. L. (1967) "The Discovery of Grounded Theory: Strategies for Qualitative Research". Aldine, London.

Glasersfeld, E. von (1984) "An Introduction to Radical Constructivism", in Watzlawick Paul [ed.] The Invented Reality: How Do We Know What We Believe We Know, Norton, New York, p. 17-40.

Glasersfeld, E. von (2001), "The Radical Constructivist View of Science", Foundations of science, vol. 6, p. 31-43.

Glasersfeld, E. von (2005), “Thirty years radical constructivism”, Constructivist Foundations, vol. $1, \mathrm{n}^{\circ} 1$, p. $9-12$.

Goldkuhl, G. (2008), “What Kind of Pragmatism in Information Systems Research?”, AIS SIG Prag Inaugural Meeting, Paris.

Goldkuhl, G. (2012), "Pragmatism vs Interpretivism in Qualitative Information Systems Research”, European Journal of Information Systems, vol. 21, n², p. 135-146.

Gregor, S. (2006), "The Nature of Theory in Information Systems", MIS Quarterly, vol. 30, n'3 p. 611-642.

Guba, E. G., Lincoln, Y. S. (1989), “Fourth Generation Evaluation”, Sage, London.

Guba, E. G., Lincoln, Y. S. (2007), "Paradigmatic Controversies, Contradictions, and Emerging Confluences", in N. K. Denzin \& Y. S. Lincoln, Handbook of Qualitative Research, Sage, London, p. 191-215.

Habermas, J. (1972), “Knowledge and Human Interest”, Heinemann, London. 
Hassan N. R. (2014), "Paradigm lost ... Paradigm gained: a Hermeneutical Rejoinder to Banville and Landry's, Can the Field of MIS be Disciplined?", European Journal of Information Systems, vol. 23, p. 600-615.

James, W. (1976), "Essays in Radical Empiricism", Harvard University Press, Cambridge. Originally published in 1912.

Johnson, P., Buehring, A., Cassel, C. and Symon G., (2006) "Evaluating Qualitative Management Research: Towards a Contingent Criteriology", International Journal of Management Reviews, vol.8, n³, p. 131-156.

Kemmis, S., McTaggart, R. (2007), "Participatory Action Research" in N. K Denzin \& Y. S. Lincoln, Strategies of Qualitative Inquiry, Sage, London.

Klein, H., Myers, M. (1999), "A Set of Principles for Conducting and Evaluating Interpretive Field Studies in Information Systems”, MIS Quarterly, vol 23, n¹, p.67-94.

Klein, H. K., Rowe, F. (2008), "Marshalling the Professional Experience of Doctoral Students: a Contribution to the Practical Relevance Debate", MIS Quarterly, vol 32, $\mathrm{n}^{\circ} 4$, p.675-686.

Keutel, M., Michalik, B., Richter, J. (2014) "Towards Mindful Case Study Research in IS: a Critical Analysis of the Past Ten Years”, European Journal of Information Systems, vol. 23, $\mathrm{n}^{\circ} 3$, p. 256-272.

Langley, A., Royer, I. (2006), "Perspectives on Doing Case Study Research in Organizations, M@n@gement, vol.9, n³,p.73-86.

Lee, A.S., Baskerville, R. L. (2003), "Generalizing Generalizability in Information Systems Research", Information Systems Research, vol. 14, n 3, p. 221-243.

Le Moigne, J-L. (1990), « La modélisation des systèmes complexes », Dunod, Paris.

Le Moigne, J-L. $(1995,2007)$, «Les Epistémologies constructivistes », $1^{\text {ère }}$ éd. ; 2007, $3^{\text {ème }}$ éd., Que Sais-Je? Paris.

Le Moigne, J-L. (2001) «Le constructivisme », Tome 1: Les Enracinements, L'Harmattan, Paris.

Lincoln, Y. S., Guba, E. G. (1985), "Naturalist inquiry”, Sage, London.

Lincoln, Y. S., Lynham, S.A. (2011), "Criteria for Assessing Theory in Human Resource Development from an Interpretive Perspective", Human Resource Development International, vol. 14, $\mathrm{n}^{\circ} 1$, February, p. 3-22.

Lindgren, R., Henfridsson, O., Schultze, U. (2004), "Design Principles for Competence Management Systems: A Synthesis of an Action Research Study", MIS Quarterly, vol. 28, $\mathrm{n}^{\circ} 3$, p. 435-472.

Markus, M. L. (1983), "Power, Politics, and MIS Implementation," Communications of the ACM (26:6) p. 430-443.

Marton, F. (1981), "Phenomenography. Describing Conceptions of the World around Us", Instructional Science, vol. 10, p. 177-200.

Mazmanian, M., Cohn, M., Dourish, P. (2014), "Dynamic reconfiguration in planetary exploration: A sociomaterial ethnography”, MIS Quarterly, vol. 38, n 3, p. 831-848.

Miller, K. D., Tsang, E. W. K. (2010), "Testing Management Theories: Critical Realist Philosophy and research Methods", Strategic Management Journal, vol. 32, p. 139-158.

Mingers, J. (2001), "Combining IS Research Methods: Towards a Pluralist Methodology", Information Systems research, vol. 12, n³, p. 240-259.

Mingers, J. (2004), "Real-izing Information Systems: Critical Realism as an Underpinning Philosophy for Information Systems", Information and Organization, vol. 14, p. 87-103.

Mingers, J. (2006), "A Critique of Statistical Modelling in Management Science from a Critical Realist Perspective: Its Role within Multimethodology", The Journal of the Operational Research Society, vol. 57, $\mathrm{n}^{\circ}$ 2, p. 202-219. 
Mingers, J., Mutch, A., Willcocks, L. (2013), "Critical Realism in Information Systems Research", MIS Quarterly, vol. 37, n³, p.795-802.

Morgan, G., Smircich, L. (1980), "The Case for Qualitative Research", Academy of Management Review, vol. 5, p. 491-500.

Myers, M. D., Klein, H. K. (2011), "A Set of Principles for Conducting Critical Research in Information Systems", MIS Quarterly, vol. 35, n 1, p. 17-36.

Ozcan, C.P., Eisenhardt, K. M. (2009). "Origin of Alliance Portfolios: Entrepreneurs, Network Strategies, and Firm Performance", Academy of Management Journal, vol. $52 \mathrm{n}^{\circ} 2$, p. 246-279.

Orlikowski, W. J., Baroundi, J.J. (1991), "Studying Information Technology in organizations: Research Approaches and Assumptions", Information Systems research, vol. 2, n 1, p. 128.

Parmentier Cajaiba, A., Avenier, M.J. (2013), "Recherches collaboratives et constructivisme pragmatique: Eclairages pratiques", Recherches Qualitatives, vol. 32, n 2, p. 201-226.

Pascal, A., Thomas, C., Romme, G. L. (2013), "Developing a Human-centred and Sciencebased Approach to Design: The Knowledge Management Platform Project", British Journal of Management, vol. 24, $\mathrm{n}^{\circ}$ 2, p. 264-280.

Piaget, J. (1967), « Logique et connaissance scientifique », Gallimard, Paris.

Pinsonneault, A., Kraemer, K. L. (1993) "The Impact of Information Technology on Middle Managers," MIS Quarterly, (17:3), September, p. 271-292.

Popper, K. R. (1959), “The logic of scientific discovery”, Harper and Row, New York.

Pratt, M. G. (2009), "From the Editors - For the Lack of a Boilerplate: Tips on Writing up (and reviewing) Qualitative Research”, Academy of Management Journal, vol. 52, n ${ }^{\circ}$, p. 856-862.

Ravishankar, M.N., Pan S.H., Myers, M.D. (2013), "Information Technology Offshoring in India: A Postcolonial Perspective", European Journal of Information Systems, vol. 21, p. 496-511.

Romme, G. L., van Burg, E. (2014), "Creating the Future Together: Toward a Framework for Research Synthesis in Entrepreneurship", Entrepreneurship Theory and Practice, vol. 38, ${ }^{\circ}$ 2, p. 369-397.

Romme, G. L., Avenier, M.J., Denyer, D., Hodgkinson, G.P. , Pandza, K., Starkey, K., Worren N. (2015), "Toward Common Ground and Trading Zones in Management Research and Practice" British Journal of Management (forthcoming).

Rowe, F. (2009), "Diversité des approches critiques en Systèmes d'Information: de la sociologie de la domination à l'éthique de l'émancipation", Economies et Sociétés, vol. $43, \mathrm{n}^{\mathrm{o}} 12$, p. $1-16$.

Sandberg, J. (2000), "Understanding Human Competence at Work: An Interpretive Approach," Academy of Management Journal, vol. 43, n 1, p. 9-25.

Sandberg, J. (2005), "How Do We Justify Knowledge Produced with Interpretive Approaches?", Organizational Research Methods, vol. 8, n 1, pp. 41-68.

Schwartz-Shea, P. (2006), "Judging Quality. Evaluative Criteria and Epistemic Communities", in Interpretation and Method: Empirical Research Methods and the Interpretive Turn, D. Yanow and P. Schwartz-Shea [eds.], M.E. Sharpe, Armonk, NY, 89113.

Siggelkow, N. (2007), "Persuasion with Case Studies", Academy of Management Journal, vol. $50, \mathrm{n}^{\circ} 1$, p. $20-24$.

Smith, M. L. (2006), "Overcoming Theory-Practice Inconsistencies: Critical Realism and Information Systems Research", Information and Organization, vol. 16, p. 191-211. 
Stigliani, I., Ravasi, D. (2012), "Organizing Thoughts and Connecting Brains: Material Practices and the Transition from Individual to Group-Level Prospective Sensemaking" Academy of Management Journal, vol. 55, $\mathrm{n}^{\circ}$ 5, p. 1232-1259.

Strauss, A., Corbin, J. (1990), "Basics of qualitative research: Grounded theory procedures and Techniques", Sage Publications, Newbury Park, CA.

Suchman, L. (1987), "Plans and Situated Actions: The Problem of Human-Machine Communication", Cambridge University Press, Cambridge UK.

Suddaby, R. (2006), "From the Editors: What Grounded Theory is Not", Academy of Management Journal, vol. 49, n 4, p. 633-642.

Suddaby, R. (2010), "Editors Comments: Construct Clarity in Theories of Management and Organization", Academy of Management Review, vol. 35, n 3, p. 346-35

Tenkasi, Ram V., Mohrman, S. A., Mohrman, A. M. Jr. (2007), "Making Knowledge Contextually Relevant: The Challenge of Connecting Academic Research with Practice", Paper presented at the annual meeting of the The 3rd Organization Studies Summer Workshop, June, Crete.

Tsang, E. W. K. (2006), "Behavioral Assumptions and Theory Development: The Case of Transaction Cost Economics", Strategic Management Journal, vol. 27, p. 999-1011.

Tsang, E. W. K., Kwan, K-M. (1999), "Replication and Theory Development in Organizational Science: A Critical Realist Perspective", Academy of Management Review, vol. 24, p. 759-780.

Tsang, E. W. K., Williams, J. N. (2012), "Generalization and Induction: Misconceptions, Clarifications, and a classification of Induction", MIS Quarterly, vol. 36, n 3, p. 729-748.

Tsoukas, H. (1989), "The Validity of Idiographic Research Explanations", Academy of Management Review, vol. 14, $\mathrm{n}^{\circ}$ 5, p. 551-561.

Tsoukas, H. (2000), "False Dilemmas in Organization Theory: Realism or Social Constructivism”, Organization, Vol. 7, $\mathrm{n}^{\circ}$ 3, pp. 531-535.

Tsoukas, H. (2011), "Craving for Generality and Small-N Studies: A Wittgensteinian Approach towards the Epistemology of the Particular in Organization and Management Studies", in David A. Buchanan and Alan Bryman (eds.), The Sage Handbook of Organizational Research Methods, Paperback Edition, p.285-301.

Van de Ven, A. H. (2007), "Engaged Scholarship: A Guide for Organizational and Social Research", Oxford University Press, Oxford.

Van den Belt, H., (2003), "How to Engage with Experimental Practices? Moderate versus Radical Constructivism", Journal for General Philosophy of Science, vol. 34, $\mathrm{n}^{\circ}$ 2, p. 201219.

Weber, R. (2004), “The Rhetoric of Positivism Versus Interpretivism: A Personal View”, MIS Quarterly, vol. 28, $\mathrm{n}^{\circ}$ 1, p. iii-xii.

Wicks, A. C., Freeman, R. E. (1998), "Organization Studies and the New Pragmatism: Positivism, Anti-positivism, and the Search for Ethics", Organization Science, vol. 9, $\mathrm{n}^{\circ} 2$, p. 123-140.

Williams, C. K., Karahanna, E. (2013,) "Causal Explanation in the Coordinating Process: A Critical Realist Case Study of Federated IT Governance Structure”, MIS Quarterly, vol. 37, $\mathrm{n}^{\circ} 3$, p. 933-964.

Wynn, D. Jr., Williams, C. K. (2012), "Principles for Conducting Critical Realist Case Study Research in Information Systems", MIS Quarterly, vol. 36, n 3, p. 787-810.

Yanow, D. (2006), "Neither Rigorous nor Objective: Interrogating Criteria for Knowledge Claims in Interpretive Science", in Interpretation and Method: Empirical Research Methods and the Interpretive Turn, D. Yanow and P. Schwartz-Shea [eds.], M.E. Sharpe, Armonk, NY, p. 67-88. 
Yanow, D., Schwartz-Shea P. [eds.] (2006), "Interpretation and Method: Empirical Research Methods and the Interpretive Turn", M.E. Sharpe, Armonk, NY.

Young, M.-L., Kuo, F.-Y., Myers, M. D. (2012), "To Share or not to Share: A Critical Research Perspective on Knowledge Management Systems", European Journal of Information Systems, vol. 21, p. 496-511.

Yin, R. K. (1989, 2009), "Case Study Research: Design and Methods", $1^{\text {st }}$ edition; 2009, $4^{\text {th }}$ edition; Sage, Thousand Oaks, CA. 